\title{
How do perceptions of inequality and opportunity affect preferences for redistribution?
}

\author{
Ugur Yildirim $^{1}$
}

September 22, 2020

\begin{abstract}
Americans' distributional preferences are known to influence their political and voting behavior, but we do not know enough about the determinants of those preferences. How do perceptions of economic inequality and economic opportunity influence redistributive preferences? I answer this question using an innovative survey experiment that jointly manipulates perceptions of economic inequality and economic opportunity. The treatments are administered in the form of videos using a new ask-then-tell design, and the sample is gathered from a novel, high-quality source of online data. I find that receiving pessimistic information about inequality makes respondents more pessimistic about the state of inequality and more supportive of government involvement; on the other hand, the addition of pessimistic information about opportunity does not lead to any more concern for inequality or support for redistribution when pessimistic information about inequality is already present. Implications for future research are discussed.
\end{abstract}

inequality | opportunity | mobility | American Dream | redistribution

\footnotetext{
${ }^{1}$ Ugur Yildirim (ugur.yildirim@berkeley.edu) is a Ph.D. candidate in the Department of Sociology, University of California-Berkeley. The author thanks Gabriel Lenz, David Harding, Daniel Schneider, Dennis Feehan, and Xinyi Zhang for all of their helpful comments, Narae Wadsworth for kindly taking the time to record the experimental texts used in the study, and UC Berkeley XLab, Don Moore in particular, for the generous research grant that funded this study.
} 


\section{Introduction}

Economic inequality in the US is high and on the rise (e.g., Piketty and Saez 2006, McCall and Percheski 2010, Alvaredo et al 2018). While Americans are not necessarily unaware or unconcerned about inequality (Bartels 2005, McCall 2013), we know that they generally prefer economic regimes that are at least somewhat unequal (Norton and Ariely 2011, Norton 2014), and that they are not particularly supportive of policies intended to address inequality, at least traditional government redistributive policies (Dallinger 2010, Shaw and Gaffey 2012, McCall $\underline{2013}, \underline{\text { McCall et al 2017). }}$

Understanding the distributional preferences of the populace is important as it affects political and voting behavior (Fisman, Jakiela, and Kariv 2017). In the US context, it is difficult to study the effect of inequality on such preferences separate from opportunity -- and related concepts such as mobility and the American Dream -- due to the crucial role these concepts play in the American culture in shaping how people understand inequality and redistribution (McCall $\underline{2013}, \underline{\text { McCall et al 2017). }}$

Considered separately, we know that perceptions of both inequality and opportunity should have an effect on preferences. However, we do not know enough about their joint effects. For example, it might be the case that while people are not bothered by inequality when there is also lots of opportunity, another situation where inequality is compounded with no opportunity could be really worrisome for most people and lead to demands for change. The joint effect could also be in the opposite direction if, for example, receiving too much pessimistic information -- "everything is going wrong in the country" -- makes people think that their own 
situation is actually not that bad compared to others, which might lead them to report more optimistic opinions about the current state of affairs and less support for government action. Alternatively, too much pessimistic information might also lead to a similar response if it triggers some sort of a "throw up your hands" response in people.

Many studies separately looked at the effect of people's perceptions of economic inequality and opportunity and claimed that both factors should have an effect on Americans' policy preferences. The median voter hypothesis stipulated that as inequality rises, support for redistribution rises as well (Meltzer and Richard 1981). While Kenworthy and McCall (2008) found little empirical support for this hypothesis, Engelhardt and Wagener (2014), Niehues (2014), Hauser and Norton (2017), and Gimpelson and Triesman (2018) all make the same point -- and support it with empirical evidence -- that what matters when it comes to policy preferences is not actual but perceived inequality.

McCall (2013) too investigates the relationship between perceptions of inequality and support for government action against inequality but finds only weak evidence for this, at least in the US. In a similar vein, Kuziemko et al (2015) finds that while information about inequality has a significant effect on Americans' views on inequality, such information is mostly ineffective in moving policy preferences, with the exception of estate tax. On the other hand, $\underline{\text { McCall et al }}$ (2017) finds that exposure to information about rising inequality actually has a significant effect on respondents' support for policies that reduce economic inequality.

Parallel to this research that studied the effect of inequality perceptions on preferences, and inspired by some of the evidence that found weak to no inequality effect in this regard, other researchers started instead from the premise that people may care more about something other 
than economic inequality, such as economic mobility, opportunity, or simply a general sense of fairness (Starmans, Sheskin, and Bloom 2017). In particular, Alesina and Angeletos (2005) proposed a model that claimed that societies where it is believed that individual effort -- as opposed to luck, family, connections, and so on -- determines income tend to favor low redistribution and low taxes.

In line with this model, Alesina and Ferrara (2005) found that Americans who believe in the existence of equal opportunity are more likely to be against redistribution. Krawczyk (2010) reached a similar conclusion that people are less willing to give to others when the community rules emphasize effort as opposed to luck. Similarly, Bjornskov et al (2013) discovered that there is a negative association between fairness perceptions and demand for equal incomes. Finally, Shariff, Wiwad, and Aknin (2016) found that perceptions of upward mobility make people more tolerant of inequality, while Alesina, Stantcheva, and Teso (2018) found that receiving pessimistic information about mobility makes respondents more supportive of redistribution.

McCall et al (2017) study inequality in conjunction with opportunity, however, their causal story has a clear order effect such that inequality perceptions affect opportunity perceptions, which then affect policy preferences. In other words, in their study, inequality and opportunity perceptions are not jointly randomized; rather, they randomize inequality perceptions and then observe how that affects opportunity perceptions and policy preferences. This study, on the other hand, theorizes inequality and opportunity as independent effects -- both randomized for each respondent -- with the aim of clearly disentangling the main as well as interaction effects related to each. 
Accordingly, this study presents results from a survey experiment that manipulates perceptions of both economic inequality and economic opportunity. The treatments are administered using an innovative ask-then-tell design that guards against the known danger of respondents rejecting treatments that are too obvious or intrusive. Furthermore, given the limitations of presenting the informational treatment in the form of a text to be read -- which usually fails to capture respondents' attention and results in null effect estimates -- this study instead presents the information treatment using video as its medium. It also uses a new, high-quality source of online data that is representative of the general population on multiple attributes.

The study has two main findings. First, inequality treatments tend to have larger direct effects -- compared to opportunity treatments -- on respondents' perceptions regarding the state of inequality in the country, general attitudes towards inequality, and concrete policy preferences. Second, and more interesting, while receiving pessimistic information about inequality makes respondents more pessimistic about the state of inequality and more supportive of government involvement, the addition of pessimistic information about opportunity does not lead to any more concern for inequality or support for redistribution when pessimistic information about inequality is already present.

The paper is structured as follows. The next section describes the methodological aspects of the study including experimental design, implementation, subject recruitment, sample characteristics, data structure, and statistical models. The section after that presents the main results of the study related to (i) perceptions, (ii) attitudes, and (iii) policy preferences. Finally, 
the last section discusses the main findings of the study, touches upon some of its limitations, and mentions ideas for future research.

\section{Methods}

\section{Experimental design}

The study is designed as a $2 \times 2$ factorial between-subjects survey experiment. The first factor is whether a respondent receives pessimistic or optimistic information about the state of economic inequality in the country. The second factor is whether the respondent receives pessimistic or optimistic information about the state of economic opportunity in the country (economic opportunity is operationalized primarily in reference to inter-generational mobility and the American Dream ideology). These two factors produce four experimental conditions (Table 1): (i) inequality optimistic, opportunity optimistic (OO); (ii) inequality optimistic, opportunity pessimistic (OP); (iii) inequality pessimistic, opportunity optimistic (PO); and (iv) inequality pessimistic, opportunity pessimistic (PP). ${ }^{2}$

The experiment flows as follows. First, respondents are recruited into the study and asked to give their consent. (At this stage, respondents are told that the goal of the survey is to “understand the public's knowledge and opinions regarding important societal and economic trends in the US." This general wording is chosen over using specific words such as inequality, opportunity, or redistribution in an attempt to make sure respondents are not primed to think about these issues from the start.) Second, they are quizzed on two relatively neutral topics (same

\footnotetext{
${ }^{2}$ See Appendix 1 for the experimental texts, images, videos, and other related content used in the study.
} 
for all respondents) and asked to watch short video clips for the answers. Third, they are quizzed on their knowledge on the state of income inequality and economic mobility in the country (the order in which the questions are asked is randomized). Upon giving their responses, the respondents are asked to watch short clips for the answers; the content of these clips depend on the experimental condition respondents are in.

Fourth, respondents answer a series of questions designed to capture their attitudes and preferences towards inequality and what to do about it (the order in which these questions are asked is also randomized). Fifth, the respondents answer two questions specifically designed to determine whether the experimental manipulations actually succeeded in changing their opinions regarding the state of economic inequality and mobility in the country (order randomized). Finally, the respondents answer a series of demographic questions, including their income and political orientation. (Most of the questions related to attitudes, preferences, and demographics as well as a large chunk of the consent text are taken directly from the study by Kuziemko et al 2015.)

\section{Implementation and subject recruitment}

The survey experiment is implemented using Qualtrics. The videos presented to respondents as part of the experiment are prepared using iMovie and subsequently uploaded to a YouTube channel specifically created for this project (videos are "unlisted", have comments disabled, and show subtitles by default). The texts narrated to respondents in the videos are recorded by a young female in her 20's speaking Standard American English. Female voice is chosen over male voice due to evidence that shows that people tend to find the female voice to be more 
credible (e.g., Siegel, Breazeal, and Norton 2009). All videos showed an Adobe Stock licensed image in the background related to the content of the narrated text. (The researcher confirmed that most respondents actually watched these videos by checking the number of YouTube "views" of each video.) The experimental texts themselves are written by the researcher after a careful reading of a series of liberal- as well as conservative- leaning news sources and research papers.

Data collection took place on Lucid Theorem. This platform gives researchers access to cheap, fast (thousands of responses within hours), and high quality data that is also nationally representative based on age, gender, ethnicity, and region. A recent scholarly work also validated the quality of Lucid samples (Coppock and McClellan 2019). Finally, while a platform like Amazon Mechanical Turk (mTurk) is highly susceptible to having respondents whose views are extremely entrenched and hard to sway due to having taken too many similar surveys, a relatively new and less used platform such as Lucid is much less susceptible to this phenomenon, and hence more suitable for this survey experiment. The project has IRB approval. (All code, materials, and de-identified data will be made public once the study is over.)

\section{Sample characteristics and data structure}

The survey experiment is run on a total of 2,800 respondents with approximately 700 respondents in each condition (Table 2). The four conditions appear to be balanced on the demographic covariates (Table 3), which gives us confidence that randomization worked as expected. All analyses are conducted on a dataset with the following simple structure: one row 
per respondent and as many columns as there are variables. Respondents are required to be US residents and 18 or older. $^{3}$

\section{Overview of statistical models used}

The outcomes in this study include binary measures (e.g., whether the respondent favors promoting equal opportunity or equal outcomes) as well as ordered ones (e.g., how much government involvement the respondent is in favor of, on a scale of 1 to 5). Despite this, all models discussed in the main text are fitted using ordinary least squares (OLS) regression -rather than (ordered) logit or probit -- for two reasons: (1) interaction terms in logit and probit models could be wrong ( $\mathrm{Ai}$ and Norton 2003); and (2) OLS is easier to interpret and discuss. With these having said, in our case, conclusions do not change if non-linear models are used instead, which is reassuring. ${ }^{4}$

Two separate models are fitted for each outcome. One model simply presents outcome means in the four experimental conditions (OO, OP, PO, PP); results from this model are very transparent and easy to interpret, and the figures presented in the Results section (Figures 1-4) are based on this model. The other model presents estimated effects associated with (i) inequality being pessimistic, (ii) opportunity being pessimistic, and (iii) the interaction of $\mathrm{i}$ and ii; results from this model are reported in the Results section when discussing inequality and opportunity effects because this is the model that directly allows us to make inferences about the direct and interactions effects (i, ii, iii) associated with these factors. Since the inclusion of demographic

\footnotetext{
${ }^{3}$ See Appendix 2 for information on sample size calculations, a discussion of additional variables included in the dataset, and a distribution of respondents across US states.

${ }^{4}$ See Appendix 3 for estimates from these alternative non-linear models.
} 
covariates does not change our conclusions, the main text only discusses models without these covariates. $^{5}$

\section{Results}

\section{Perceptions regarding inequality, opportunity, and mobility}

The first set of models fit to data estimate the effect of the experimental conditions on respondents' perceptions regarding the state of inequality and mobility in the country. The outcomes here are (i) respondents' sense of whether the income gap between richer and poorer Americans are decreasing (1), staying the same (2), or increasing (3); and (ii) respondents' sense of whether American children today have better (1), same (2), or worse (3) chances economically compared to their parents. These two outcomes are deliberately worded to reflect the core ideas in the two informational treatment axes so that they can be used to confirm that the experiment successfully moved respondents' opinions in the expected direction.

Results strongly suggest that the experiment worked as planned. Receiving pessimistic information about inequality makes respondents more likely to say that the gap between the rich and the poor is increasing in the country (coefficient estimate: 0.196 , p-value: $<0.001$ ); receiving pessimistic information about opportunity has a smaller -- about half as large -- effect on this outcome (coefficient estimate: 0.106 , p-value: 0.004). On the other hand, receiving pessimistic information about opportunity makes respondents more likely to say that children today have worse chances economically compared to parents (coefficient estimate: 0.606 , p-value: $<0.001$ );

\footnotetext{
${ }^{5}$ See Appendix 4 for tables with estimated coefficients, standard errors, and p-values; results both with and without demographic covariates are presented for the sake of transparency (Lenz and Sahn 2020). See Appendix 5 for additional models that further interact experimental manipulations with political orientation.
} 
there is no significant inequality effect here (coefficient estimate: 0.004 , p-value: 0.923 ). See Figure 1 for the outcome means in the four conditions corresponding to these estimated inequality and opportunity effects.

In addition to these two key outcomes, additional models were fit to data to understand the effect of the experimental conditions on respondents' sense of their own mobility experience. The relevant outcomes here are (i) respondents' sense of whether their own standard of living is much better (1), somewhat better (2), about the same (3), somewhat worse (4), or much worse (5) compared to their parents (inter-generational mobility); and (ii) respondents' sense of whether their standard of living is much better (1), somewhat better (2), about the same (3), somewhat worse (4), or much worse (5) compared to 10 years ago (intra-generational mobility). (Note that these variables are coded such that higher values denote reports of downward mobility; this coding is chosen to ensure that the direction in which the estimates move are consistent across models.)

Results suggest that the experimental manipulations affected not just respondents' sense of the general state of inter-generational mobility and opportunity in the country (as the outcome related to economic chances of American children compared to parents showed above) but also their sense of their own mobility experience. In particular, receiving pessimistic information about opportunity made respondents more likely to report a more downward mobility experience (inter-generational mobility, coefficient estimate: 0.293, p-value: $<0.001$; intra-generational mobility, coefficient estimate: 0.200, p-value: 0.002). See Figure 2 for the outcome means in the four conditions corresponding to these estimated inequality and opportunity effects. 
One interesting pattern in the case of inter-generational mobility is that the interaction effect associated with receiving pessimistic information about both inequality and opportunity is negative and significant (coefficient estimate: -0.225 , p-value: 0.014 ), which indicates that pessimistic information along both axes actually made respondents less likely to choose a more downward inter-generational mobility category. This interesting pattern can also be seen by observing that the outcome mean is lower under PP (both pessimistic) compared to OP (only opportunity pessimistic) in the left panel of Figure 2 .

\section{General attitudes towards inequality}

The second set of models fit to data estimate the effect of the experimental conditions on respondents' general attitudes towards inequality and related concepts. The relevant outcomes here are (i) whether respondents think one's income and position in society has more to do with individual effort (0) or circumstances (1); (ii) whether respondents favor equal opportunity (0) or equal outcomes (1); (iii) respondents' opinions regarding the role of government vis-à-vis its citizens (1: provide basic functions only, 5: take active steps to improve the lives of citizens); (iv) whether respondents think inequality in America is a problem or not (1: not a problem at all, 5: a very serious problem); and (v) whether respondents think high earners deserve their high incomes most of the time (1), sometimes (2), or rarely (3).

Results show that while the experimental conditions did not have discernible effects on the (i) individual effort vs. circumstances, (ii) equal opportunity vs. equal outcomes, and (iii) high earners deserving or not outcomes (see Figure A4.1, Table A4.2), we have evidence that shows that the other two outcomes have been significantly affected by our experimental 
manipulations. More specifically, receiving pessimistic information about inequality leads respondents to (i) support more government involvement (coefficient estimate: 0.198, p-value: 0.007 ) and (ii) think that inequality is a serious problem (coefficient estimate: 0.270 , p-value: $<0.001$ ). The opportunity effect is also significant in the latter case, albeit smaller (coefficient estimate: 0.201 , p-value: 0.001 ). See Figure 3 for the outcome means in the four conditions corresponding to these estimated inequality and opportunity effects.

In both of these cases, the interaction is significant and negative (government involvement, coefficient estimate: -0.261 , p-value: 0.012 ; inequality serious problem, coefficient estimate: -0.211, p-value: 0.016). Substantively, this means that receiving pessimistic information along both axes does not make respondents any more supportive of government involvement or more likely to think inequality is a serious problem when pessimistic information about inequality is already present. As a matter of fact, as can be seen in the left panel of Figure 3 , in the case of government involvement, the interaction effect pushes the PP estimate to be statistically significantly lower compared to PO, which means that respondents are actually more supportive of government involvement when only inequality is pessimistic (PO) compared to when both inequality and opportunity is pessimistic (PP).

\section{Concrete policy preferences}

The third set of models fit to data estimate the effect of the experimental conditions on respondents' concrete preferences towards policies that address inequality. The survey experiment included the following seven policy outcomes: (i) whether respondents think taxes on millionaires should be decreased (1), stay the same (2), or increased (3); (ii) whether respondents 
think the estate tax should be decreased (1), stay the same (2), or increased (3); (iii) whether respondents think the minimum wage should be decreased (1), stay the same (2), or increased (3); (iv) whether respondents think aid to the poor should be decreased or increased (1: significantly decreased, 5: significantly increased); (v) whether respondents think government spending on food stamps should be decreased or increased (1: significantly decreased, 5: significantly increased); (vi) whether respondents think government should support entrepreneurs (0: no, 1: yes); and (vii) whether respondents think government should support people in the face of high housing costs (0: no, 1: yes).

Results show that receiving pessimistic information about inequality leads respondents to support (i) increasing the estate tax (coefficient estimate: 0.079, p-value: 0.041), (ii) increasing the minimum wage (coefficient estimate: 0.088, p-value: 0.002), and (iii) government support in the face of high housing costs (coefficient estimate: 0.038 , p-value: 0.051 , barely insignificant). There is also a nearly significant opportunity effect (coefficient estimate: 0.056 , p-value: 0.052 ) and a significant negative interaction effect (coefficient estimate: -0.090 , p-value: 0.027 ) in the case of minimum wage. See Figure 4 for the outcome means in the four conditions corresponding to these estimated inequality and opportunity effects.

In all three of these outcomes, the PP estimate is lower compared to the PO estimate (statistically significant in the case of support housing), which indicates that receiving pessimistic information along both axes does not make respondents any more supportive of redistribution when pessimistic information about inequality is already present. On the contrary, the PP estimate tends to be lower compared to the PO estimate, though the difference is usually not statistically significant. This general pattern of the PP estimate being lower compared to the 
PO estimate emerges in five out of the seven policy outcomes (see Figure A4.1, Table A4.3 for the other four policy outcomes not presented here).

\section{Discussion}

The most interesting pattern observed in the results is that while receiving pessimistic information about inequality makes respondents more pessimistic about the state of inequality and more supportive of government involvement, the addition of pessimistic information about opportunity does not lead to any more concern for inequality or support for redistribution when pessimistic information about inequality is already present. One way to interpret these results is that the idea of high and rising inequality might automatically conjure up feelings of lack of opportunity in people regardless of whether opportunity is directly discussed or not. In other words, even if an individual actually finds the combination of high inequality and no opportunity worrisome, pessimistic information regarding inequality might already imply a pessimistic state of opportunity, which would explain why pessimistic information about opportunity does not have much of an added impact.

Beyond this, some of the results further indicated that not only does pessimism along both axes not make respondents any more pessimistic about the state of inequality and supportive of government involvement, it might actually have the opposite effect. For example, evidence suggested that respondents are more supportive of government involvement when they have a pessimistic sense of inequality and an optimistic sense of opportunity compared to when their senses of both inequality and opportunity are pessimistic. One possible way to make sense of these unexpected results is that when respondents are made to believe that everything is going 
wrong in the country, this may make them think that their own situation is actually not that bad, which leads them to report more optimistic opinions and less support for government action. Results related to respondents' sense of their own inter-generational mobility experience support this view (left panel of Figure 2).

As far as the direct effects of the treatments on respondents' perceptions, attitudes, and policy preferences vis-à-vis inequality are concerned, the inequality axis is more influential compared to the opportunity one. While we have evidence that suggests that receiving pessimistic information about inequality and opportunity both make respondents more likely to think that (i) the income gap is widening, (ii) inequality is a serious problem, and (iii) the government should take a more active role in helping its citizens, the estimated inequality effects are consistently larger compared to the estimated opportunity effects. Furthermore, when it comes to concrete policy preferences, while no significant opportunity effects are detected, receiving pessimistic information about inequality makes respondents more likely to support (i) increasing the estate tax, (ii) increasing the minimum wage, and (iii) government helping people in the face of high housing costs.

There is no indication that the opportunity manipulation was inherently weak -- which could have explained the small and null effect estimates -- as this manipulation had strong effects on outcomes related to mobility (right panel of Figure 1, left and right panels of Figure 2). While there is no indication that the inequality treatment had any effect on respondents' sense of whether children today have better or worse chances economically compared to their parents, the opportunity treatment -- which explicitly refers to inter-generational mobility -- had a big impact on this, making respondents more likely to think that children have worse chances. Similarly, the 
inequality treatment had at best a weak effect on respondents' sense of their own mobility experience, while receiving pessimistic information about the state of opportunity in the country made respondents more likely to report downward mobility.

As far as the limitations of the study are concerned, the fact that the study does not have neutral conditions could be seen as a shortcoming in the sense that none of the conditions is explicitly a "control." Accordingly, future studies might consider also including neutral conditions in addition to the optimistic and pessimistic conditions tried in this study. Of course, the main challenge there is to find informational treatments that are truly neutral such that the estimated neutral vs. optimistic and neutral vs. pessimistic effects could be trusted. Another possible limitation of the study is that it is not based on a probability sample. While the Lucid sample used in this study is representative of the population on a number of attributes, it is still technically a convenience sample. Future researchers might consider trying to replicate the findings in this study on a true probability sample to make inferences about the US populace easier.

Beyond these two potential shortcomings, it should also be remembered that perceptions of inequality and opportunity are not the only factors that affect a person's attitudes and preferences. As discussed in Kuziemko et al (2015), and before that in Bartels 2005, one possible reason why Americans might not support government action on inequality is that they fail to make the connection between social issues and public policy. Another reason, also discussed in Kuziemko et al (2015), could be related to Americans' low trust in government. It is probably worthwhile to estimate both of these effects -- ability to make connections between social issues 
and public policy and level trust in government -- in a similar experiment such as the one used in this study.

Finally, I expect my finding regarding the interesting way in which perceptions of inequality and opportunity interact to influence general attitudes towards inequality and concrete policy preferences to open up a wealth of new questions to investigate. For example, when does pessimistic information about society lead an individual to become pessimistic about their own situation? And, does pessimism ever become too much so that the individual loses their faith in the possibility of fixing the system?

\section{References}

Ai, C. and E. Norton. 2003. "Interaction terms in logit and probit models." Economics Letters 80(1): 123-129.

Alesina, A. and G. Angeletos. 2005. "Fairness and Redistribution." The American Economic Review 95(4): 960-980.

Alesina, A. and E. Ferrara. 2005. "Preferences for redistribution in the land of opportunities." Journal of Public Economics 89: 897-931.

Alesina, A., S. Stantcheva, and E. Teso. 2018. "Intergenerational Mobility and Preferences for Redistribution." American Economic Review 108(2): 521-554.

Alvaredo, F., L. Chancel, T. Piketty, E. Saez, G. Zucman. 2018. “The Elephant Curve of Global Inequality and Growth.” AEA Papers and Proceedings 108: 103-108.

Bartels, L. 2005. "Homer Gets a Tax Cut: Inequality and Public Policy in the American Mind." Perspectives on Politics 3(1): 15-31. 
Bjornskov, C., A. Dreher, J. Fischer, J. Schnellenbach, and K. Gehring. 2013. "Inequality and Happiness: When Perceived Social Mobility and Economic Reality Do Not Match.” Journal of Economic Behavior and Organization 91: 75-92.

Coppock, A. and O. McClellan. 2019. "Validating the demographic, political, psychological, and experimental results obtained from a new source of online survey respondents." Research and Politics January-March: 1-14.

Dallinger, U. 2010. "Public support for redistribution: what explains cross-national differences?" Journal of European Social Policy 20(4): 333-349.

Engelhardt, C. and A. Wagener. 2014. "Biased Perceptions of Income Inequality and Redistribution.” CESifo Working Paper Series No. 4838.

Fisman, R., P. Jakiela, and S. Kariv. 2017. "Distributional preferences and political behavior." Journal of Public Economics 155: 1-10.

Gimpelson, V. and D. Treisman. 2018. "Misperceiving Inequality." Economics \& Politics 30: $27-54$.

Hauser, O. and M. Norton. 2017. "(Mis)perceptions of inequality." Current Opinion in Psychology 18: 21-25.

Kenworthy, L. and L. McCall. 2008. "Inequality, public opinion and redistribution." Socio-Economic Review 6(1): 35-68.

Kuziemko, I., M. Norton, E. Saez, and S. Stantcheva. 2015. "How Elastic Are Preferences for Redistribution? Evidence from Randomized Survey Experiments." American Economic Review 105(4): 1478-1508. 
Krawczyk, M. 2010. “A glimpse through the veil of ignorance: Equality of opportunity and support for redistribution.” Journal of Public Economics 94: 131-141.

Lenz, G. and A. Sahn. 2020. “Achieving Statistical Significance with Control Variables and without Transparency." Working Paper.

McCall, L. 2013. The Undeserving Rich: American Beliefs about Inequality, Opportunity, and Redistribution. New York: Cambridge University Press.

McCall, L. and C. Percheski. 2010. "Income Inequality: New Trends and Research Directions.” Annual Review of Sociology 36: 329-347.

McCall, L., D. Burk, M. Laperriere, and J. Richeson. 2017. "Exposure to rising inequality shapes Americans' opportunity beliefs and policy support.” PNAS 114(36): 9593-9598.

Meltzer, A., and S. Richers. 1981. “A Rational Theory of the Size of Government.” Journal of Political Economy 89(5): 914-927.

Niehues, J. 2014. "Subjective Perceptions of Inequality and Redistributive Preferences: An International Comparison." IW-Trends No. 2.

Norton, M. and D. Ariely. 2011. "Building a Better America-One Wealth Quintile at a Time." Perspectives on Psychological Science 6(1): 9-12.

Norton, M. 2014. "Unequality: Who Gets What and Why It Matters." Policy Insights from the Behavioral and Brain Sciences 1(1): 151-155.

Piketty, T. and E. Saez. 2006. “The Evolution of Top Incomes: A Historical and International Perspective." AEA Papers and Proceedings 96(2): 200-205. 
Shariff, A., D. Wiwad, and L. Aknin. 2016. "Income Mobility Breeds Tolerance for Income Inequality: Cross-National and Experimental Evidence.” Perspectives on Psychological Science 11(3): 373-380.

Shaw, G. and L. Gaffey. 2012. "Trends: American Public Opinion on Economic Inequality, Taxes, and Mobility: 1990-2011." Public Opinion Quarterly 76(3): 576-596.

Siegel, M., C. Breazeal, and M. Norton. 2009. "Persuasive Robotics: The influence of robot gender on human behavior." IEEE/RSJ International Conference on Intelligent Robots and Systems October 11-15: 2563-2568.

Starmans, C., M. Sheskin, and P. Bloom. 2017. "Why people prefer unequal societies." Nature Human Behaviour 1: 0082. 


\section{Tables}

Table 1. Experimental conditions.

\begin{tabular}{|l|l|l|}
\hline & Opportunity optimistic & Opportunity pessimistic \\
\hline Inequality optimistic & OO & OP \\
\hline Inequality pessimistic & PO & PP \\
\hline
\end{tabular}

Table 2. Number of respondents by condition.

\begin{tabular}{|l|l|}
\hline Condition & Number of respondents \\
\hline Inequality optimistic, opportunity optimistic (OO) & 713 \\
\hline Inequality optimistic, opportunity pessimistic (OP) & 685 \\
\hline Inequality pessimistic, opportunity optimistic (PO) & 697 \\
\hline Inequality pessimistic, opportunity pessimistic (PP) & 705 \\
\hline Total & 2,800 \\
\hline
\end{tabular}

Table 3. Demographics by condition.

\begin{tabular}{|c|c|c|c|c|}
\hline & $\mathrm{OO}$ & OP & $\mathrm{PO}$ & PP \\
\hline Age & 44.735 & 44.559 & 44.188 & 44.861 \\
\hline \multicolumn{5}{|l|}{ Gender } \\
\hline Male & 0.496 & 0.466 & 0.481 & 0.494 \\
\hline Female & 0.501 & 0.531 & 0.518 & 0.502 \\
\hline Other & 0.003 & 0.003 & 0.001 & 0.004 \\
\hline \multicolumn{5}{|l|}{ Marital status } \\
\hline Single & 0.586 & 0.587 & 0.594 & 0.596 \\
\hline Married & 0.414 & 0.413 & 0.406 & 0.404 \\
\hline \multicolumn{5}{|l|}{ Has children living with them } \\
\hline No & 0.621 & 0.599 & 0.626 & 0.631 \\
\hline Yes & 0.379 & 0.401 & 0.374 & 0.369 \\
\hline \multicolumn{5}{|l|}{ Ethnicity/race } \\
\hline European American/White & 0.673 & 0.689 & 0.679 & 0.692 \\
\hline African American/Black & 0.119 & 0.139 & 0.122 & 0.123 \\
\hline Hispanic/Latino & 0.109 & 0.080 & 0.103 & 0.091 \\
\hline Asian/Asian American & 0.049 & 0.034 & 0.049 & 0.055 \\
\hline Other & 0.049 & 0.058 & 0.047 & 0.038 \\
\hline
\end{tabular}




\begin{tabular}{|c|c|c|c|c|}
\hline \multicolumn{5}{|l|}{ Highest level of education } \\
\hline Eighth Grade or Less & 0.007 & 0.006 & 0.004 & 0.003 \\
\hline Some High School & 0.035 & 0.035 & 0.042 & 0.034 \\
\hline High School Degree/GED & 0.258 & 0.247 & 0.263 & 0.251 \\
\hline Some College & 0.251 & 0.266 & 0.270 & 0.260 \\
\hline 2-year College Degree & 0.129 & 0.127 & 0.129 & 0.132 \\
\hline 4-year College Degree & 0.203 & 0.210 & 0.189 & 0.224 \\
\hline Master's Degree & 0.086 & 0.091 & 0.070 & 0.077 \\
\hline Doctoral Degree & 0.017 & 0.004 & 0.014 & 0.010 \\
\hline Professional Degree (JD, MD, MBA) & 0.014 & 0.015 & 0.019 & 0.010 \\
\hline \multicolumn{5}{|l|}{ Employment status } \\
\hline Full-time employee & 0.391 & 0.364 & 0.397 & 0.400 \\
\hline Part-time employee & 0.095 & 0.104 & 0.105 & 0.087 \\
\hline Self-employed or small business owner & 0.074 & 0.085 & 0.086 & 0.078 \\
\hline Unemployed and looking for work & 0.102 & 0.096 & 0.072 & 0.098 \\
\hline Student & 0.066 & 0.061 & 0.052 & 0.050 \\
\hline Not in labor force (for example: retired, or full-time parent) & 0.271 & 0.291 & 0.288 & 0.288 \\
\hline \multicolumn{5}{|l|}{ Total household income before taxes } \\
\hline$\$ 0-\$ 9,999$ & 0.093 & 0.096 & 0.083 & 0.095 \\
\hline$\$ 10,000-\$ 14,999$ & 0.052 & 0.048 & 0.067 & 0.052 \\
\hline$\$ 15,000-\$ 19,999$ & 0.065 & 0.069 & 0.080 & 0.064 \\
\hline$\$ 20,000-\$ 29,999$ & 0.123 & 0.128 & 0.122 & 0.122 \\
\hline$\$ 30,000-\$ 39,999$ & 0.132 & 0.140 & 0.112 & 0.140 \\
\hline$\$ 40,000-\$ 49,999$ & 0.108 & 0.101 & 0.099 & 0.104 \\
\hline$\$ 50,000-\$ 74,999$ & 0.191 & 0.150 & 0.202 & 0.194 \\
\hline$\$ 75,000-\$ 99,999$ & 0.098 & 0.107 & 0.086 & 0.106 \\
\hline$\$ 100,000-\$ 124,999$ & 0.059 & 0.070 & 0.066 & 0.041 \\
\hline$\$ 125,000-\$ 149,999$ & 0.028 & 0.045 & 0.036 & 0.038 \\
\hline$\$ 150,000-\$ 199,999$ & 0.028 & 0.025 & 0.029 & 0.027 \\
\hline$\$ 200,000+$ & 0.024 & 0.020 & 0.017 & 0.016 \\
\hline \multicolumn{5}{|l|}{ Liberal/conservative spectrum } \\
\hline Very conservative & 0.128 & 0.112 & 0.113 & 0.145 \\
\hline Conservative & 0.210 & 0.207 & 0.221 & 0.209 \\
\hline Moderate & 0.425 & 0.429 & 0.418 & 0.423 \\
\hline Liberal & 0.164 & 0.171 & 0.169 & 0.162 \\
\hline Very liberal & 0.073 & 0.080 & 0.079 & 0.062 \\
\hline \multicolumn{5}{|l|}{ Party identity } \\
\hline Republican & 0.292 & 0.280 & 0.310 & 0.315 \\
\hline Democrat & 0.367 & 0.406 & 0.383 & 0.356 \\
\hline Independent & 0.288 & 0.244 & 0.242 & 0.267 \\
\hline None & 0.053 & 0.070 & 0.065 & 0.062 \\
\hline
\end{tabular}

Age is in years. All other numbers presented are proportions. 


\section{Figures}
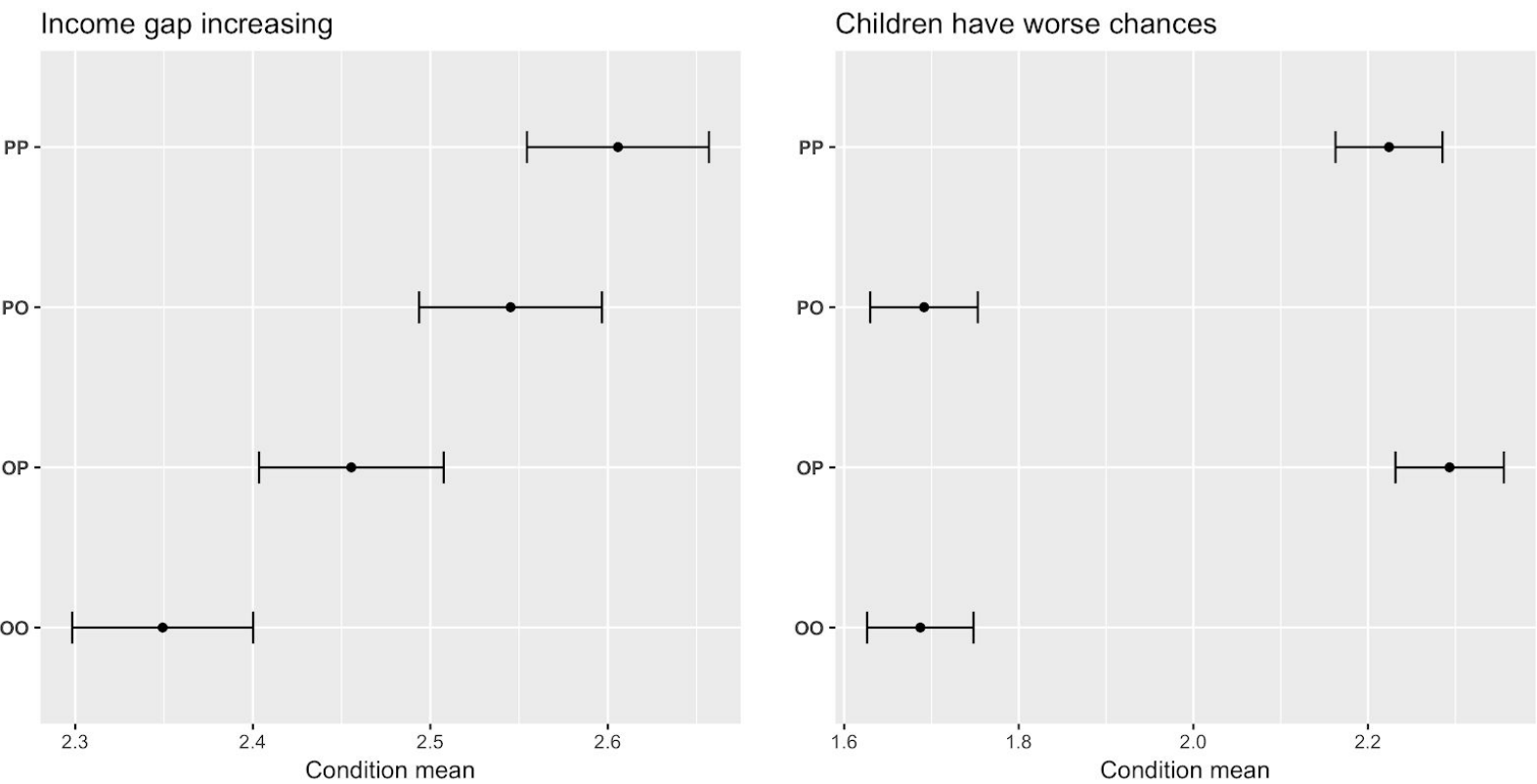

Fig. 1. Perceptions regarding inequality and opportunity (predicted means). The bars denote $95 \%$ confidence intervals. PP: inequality pessimistic, opportunity pessimistic; PO: inequality pessimistic, opportunity optimistic; OP: inequality optimistic, opportunity pessimistic; OO: inequality optimistic, opportunity optimistic.
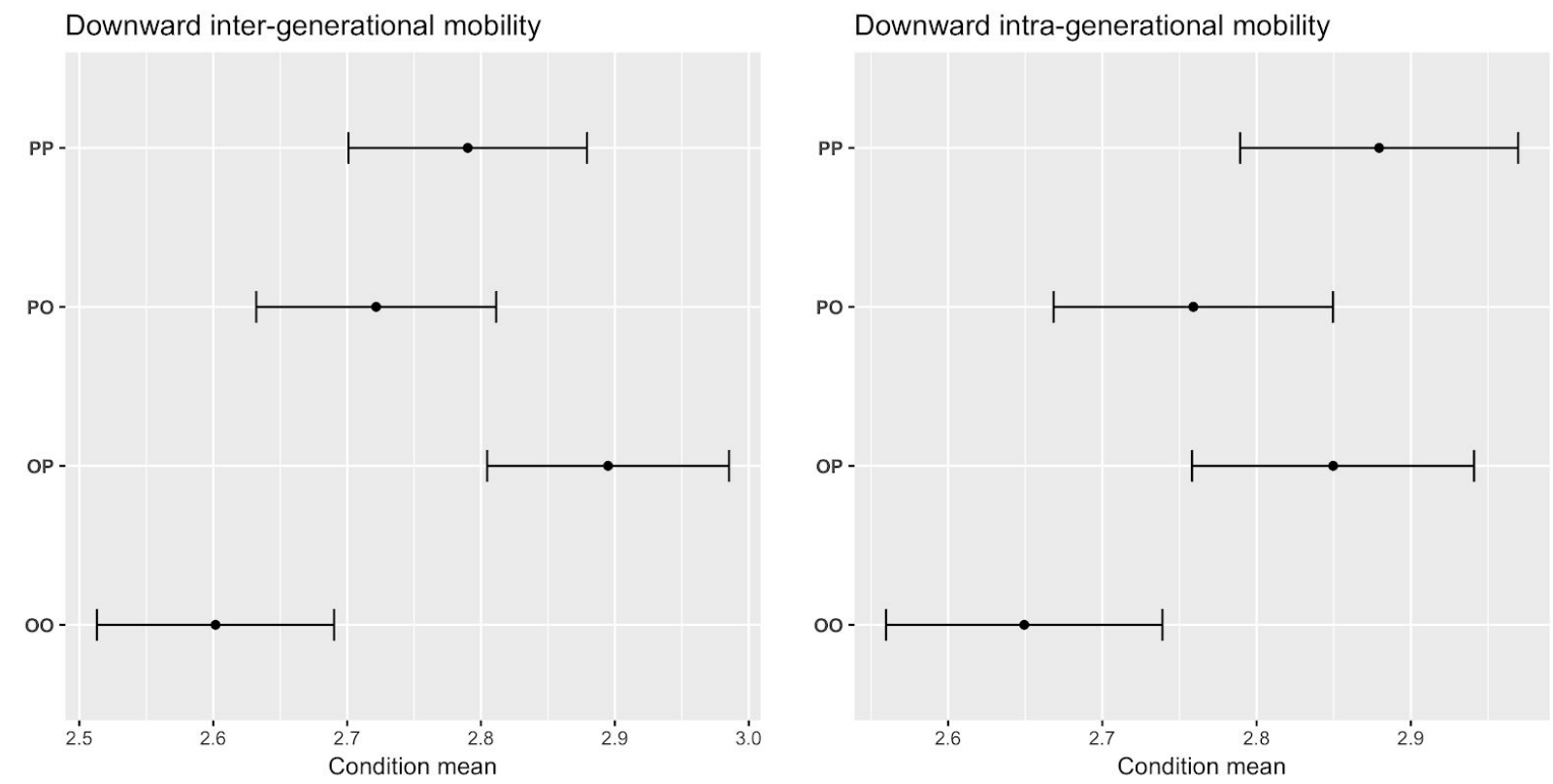

Fig. 2. Perceptions regarding mobility (predicted means). The bars denote $95 \%$ confidence intervals. PP: inequality pessimistic, opportunity pessimistic; PO: inequality pessimistic, opportunity optimistic; OP: inequality optimistic, opportunity pessimistic; OO: inequality optimistic, opportunity optimistic. 

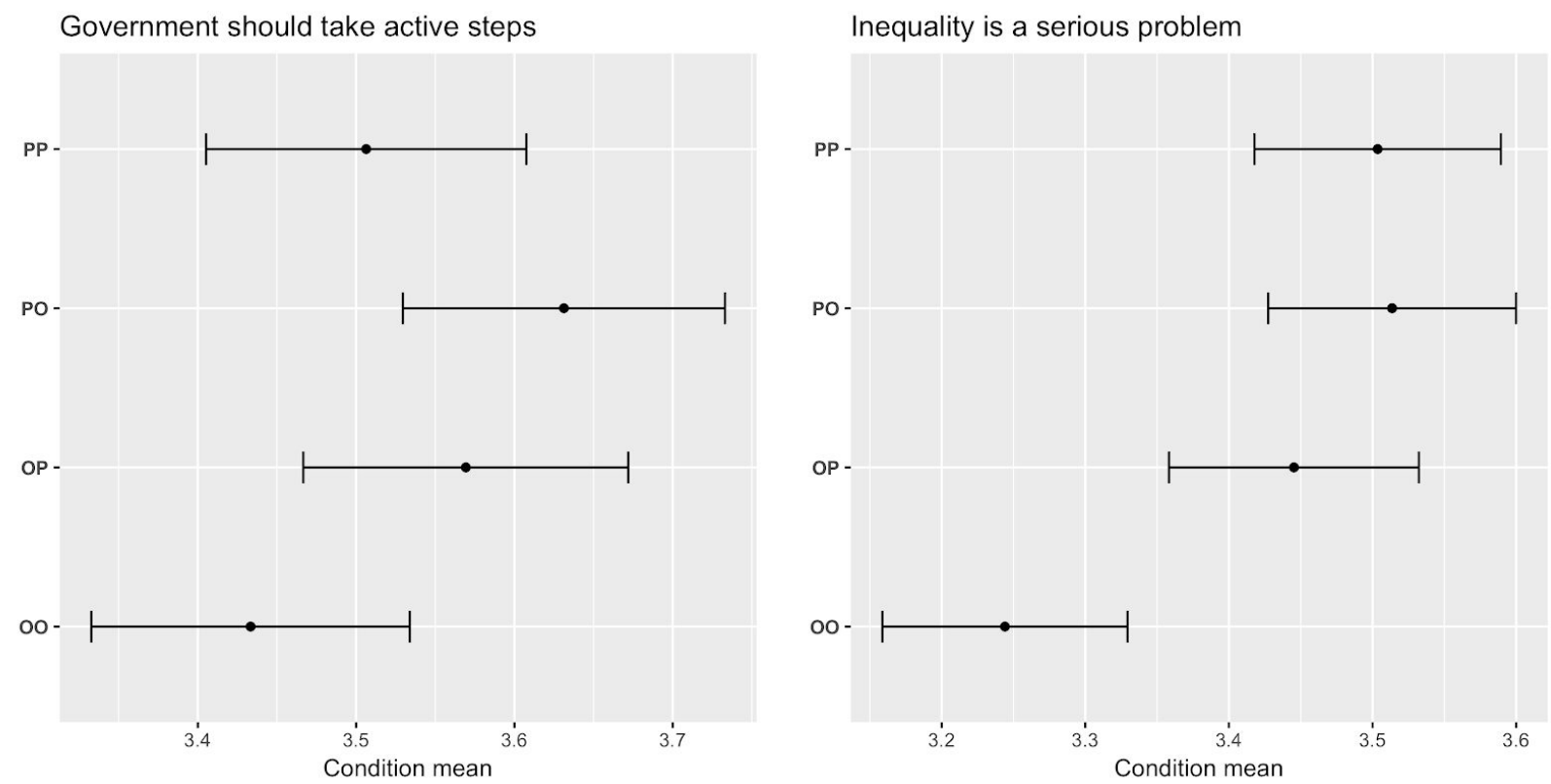

Fig. 3. General attitudes towards inequality (predicted means). The bars denote $95 \%$ confidence intervals. PP: inequality pessimistic, opportunity pessimistic; PO: inequality pessimistic, opportunity optimistic; OP: inequality optimistic, opportunity pessimistic; OO: inequality optimistic, opportunity optimistic.
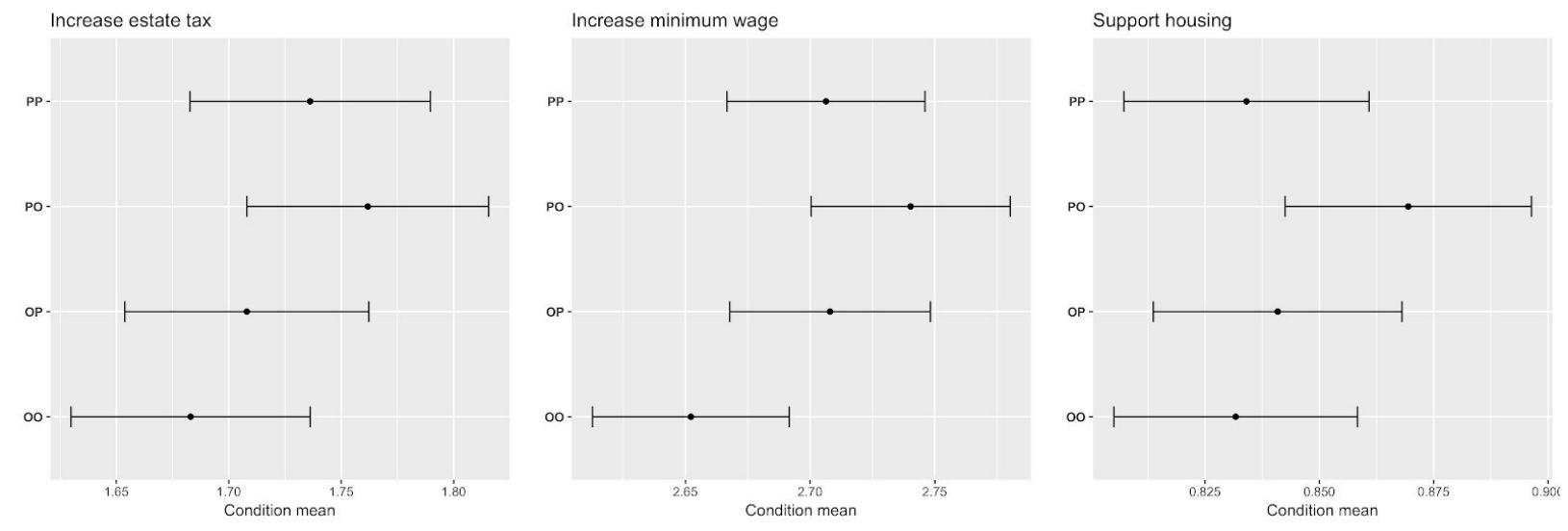

Fig. 4. Concrete policy preferences (predicted means). The bars denote $95 \%$ confidence intervals. PP: inequality pessimistic, opportunity pessimistic; PO: inequality pessimistic, opportunity optimistic; OP: inequality optimistic, opportunity pessimistic; OO: inequality optimistic, opportunity optimistic. 


\section{Appendix 1: Experimental texts, images, videos, and other related content}

Those interested in seeing how the survey looked like from the respondents' perspective can take the survey for themselves by going to this link [link removed for blind review]. The complete set of texts and figures as well as links to the videos used in the experiment are provided below. (As also mentioned in the main text, most of the questions related to attitudes, preferences, and demographics as well as a large chunk of the consent text are taken directly from the study by Kuziemko et al 2015.)

\section{Welcome to our survey!}

The goal of this survey is to understand the public's knowledge and opinions regarding important societal and economic trends in the US.

At no point in the survey should you feel obligated to answer in a particular way; the most important factor for the success of our research is that you answer honestly. Anytime you don't know an answer, just give your best guess.

It is also very important for the success of our research project that you complete the survey until the end, once you have started. This survey should take (on average) about 10 to 15 minutes to complete.

\section{Notes:}

Your participation in this study is purely voluntary, and you may withdraw your participation or your data at any time without any penalty to you. Your name will never be recorded. Results may include summary data, but you will never be identified. If you have any questions about this study, you may contact us at [e-mail address removed for blind review ].

YOU MUST BE A US RESIDENT TO PARTICIPATE IN THIS SURVEY

- Yes, I would like to take part in this study, and confirm that I AM A US RESIDENT and am 18 or older

- No, I would not like to participate

IF ANSWER = Yes

CONTINUE

ELSE

END SURVEY 
We'll start by giving you a short quiz related to some societal and economic trends in the US.

Note: the answers to the questions will be presented in the form of a video, so be prepared to watch a short clip with subtitles. Simply press [YouTube play symbol] to hear the answer! 
What percentage of Americans do you think rank strengthening the economy as a top priority?

- Less than $50 \%$

- Around $50 \%$

- More than $50 \%$

IF ANSWER $=$ More than $50 \%$

That is correct! Many polls have shown that the overwhelming majority of Americans view strengthening the economy as a top priority. One recent poll conducted by a respectable research center found that about $70 \%$ of Americans consider this issue a top priority.

THIS TEXT IS PRESENTED TO RESPONDENTS IN AN UNLISTED YOUTUBE VIDEO WITH SUBTITLES AND THE FOLLOWING LICENSED ADOBE STOCK IMAGE IN THE BACKGROUND.

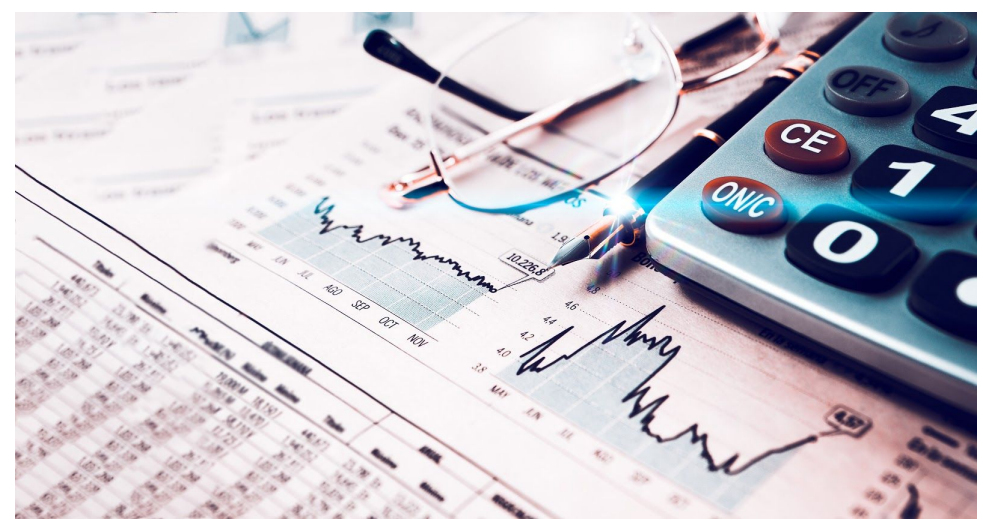

(c) carloscastilla - Adobe Stock

\section{LINK TO VIDEO}

\section{ELSE}

Not quite. Many polls have shown that the overwhelming majority of Americans view strengthening the economy as a top priority. One recent poll conducted by a respectable research center found that about $70 \%$ of Americans consider this issue a top priority.

THIS TEXT IS PRESENTED TO RESPONDENTS IN AN UNLISTED YOUTUBE VIDEO WITH SUBTITLES AND THE FOLLOWING LICENSED ADOBE STOCK IMAGE IN THE BACKGROUND. 


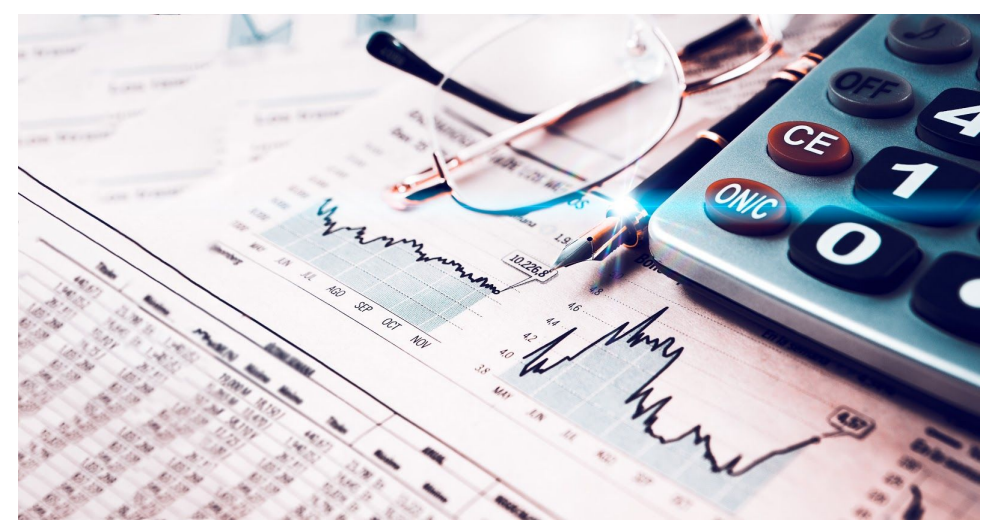

(C) carloscastilla - Adobe Stock

\section{LINK TO VIDEO}


What percentage of American teens do you think work during the summer?

- Less than $50 \%$

- Around $50 \%$

- More than $50 \%$

IF ANSWER $=$ Less than $50 \%$

That is correct! Recent polls have shown that less than $50 \%$ of American teens work during the summer. One recent poll conducted by a respectable research center found that $35 \%$ of American teens between the ages 16 to 19 have summer jobs.

THIS TEXT IS PRESENTED TO RESPONDENTS IN AN UNLISTED YOUTUBE VIDEO WITH SUBTITLES AND THE FOLLOWING LICENSED ADOBE STOCK IMAGE IN THE BACKGROUND.

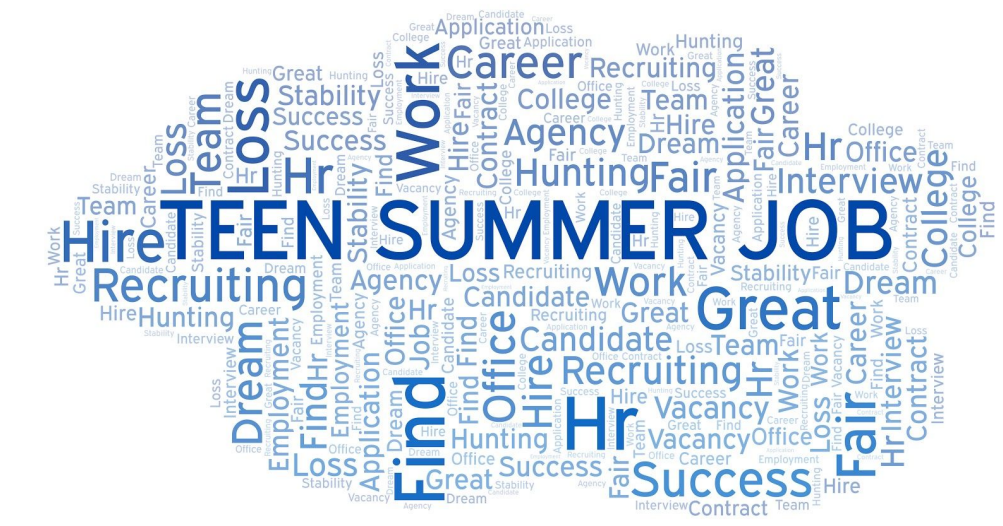

(C) sharafmaksumov - Adobe Stock

LINK TO VIDEO

ELSE

Not quite. Recent polls have shown that less than $50 \%$ of American teens work during the summer. One recent poll conducted by a respectable research center found that $35 \%$ of American teens between the ages 16 to 19 have summer jobs.

THIS TEXT IS PRESENTED TO RESPONDENTS IN AN UNLISTED YOUTUBE VIDEO WITH SUBTITLES AND THE FOLLOWING LICENSED ADOBE STOCK IMAGE IN THE BACKGROUND. 


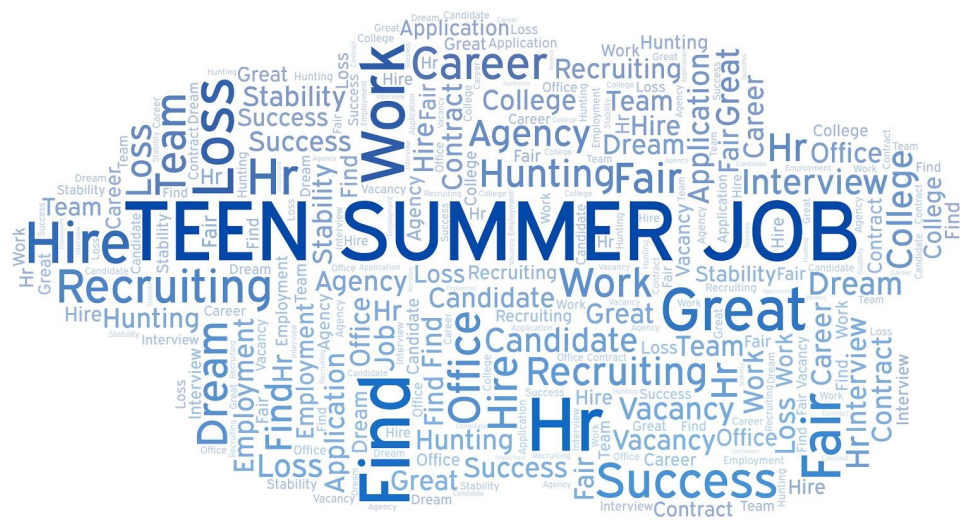

(C) sharafmaksumov - Adobe Stock

LINK TO VIDEO 
EXPERIMENTAL MANIPULATIONS START HERE.

FIRST, RANDOMLY DECIDE WHETHER TO SHOW INEQUALITY OR MOBILITY QUESTION FIRST.

THEN, RANDOMLY DECIDE WHETHER TO SHOW THE PESSIMISTIC OR THE OPTIMISTIC TREATMENT. 


\section{Do you think income inequality in the US has increased or decreased in recent}

decades?

[Income inequality can be defined as the income gap between richer and poorer Americans. High inequality generally means less wealth for most Americans, while low inequality generally means more wealth.]

- Decreased (More wealth for most)

- Stayed the same

- Increased (Less wealth for most)

IF INEQUALITY CONDITION = PESSIMISTIC

IF ANSWER = Increased (Less wealth for most)

That is correct! Income inequality in the US has rapidly increased in recent decades, reaching extreme levels. Based on a recent report published by a group of prominent researchers, while typical earners experienced only a meager 7\% increase in their wages between 2000 and 2018, the richest 5\% experienced a $25 \%$ increase in earnings.

THIS TEXT IS PRESENTED TO RESPONDENTS IN AN UNLISTED YOUTUBE VIDEO WITH SUBTITLES AND THE FOLLOWING LICENSED ADOBE STOCK IMAGE IN THE BACKGROUND.

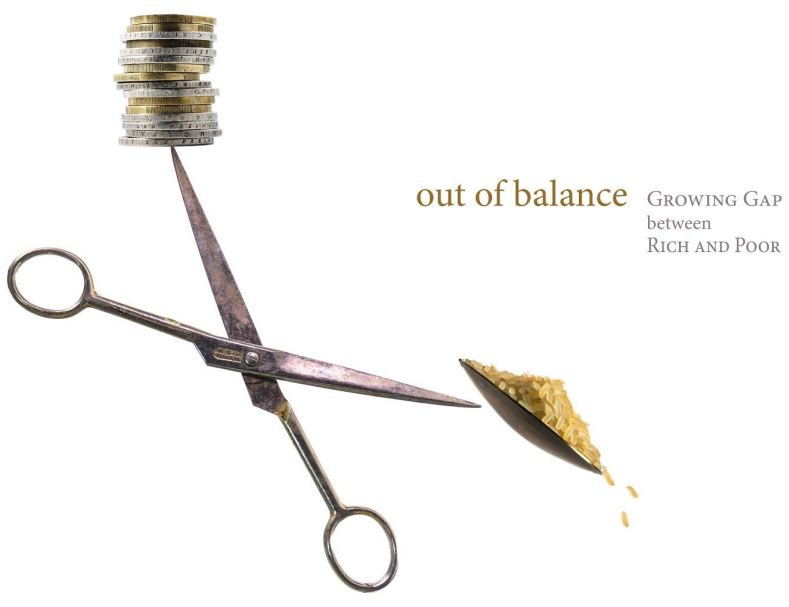

(c) Maren Winter - Adobe Stock

LINK TO VIDEO 
Not quite. Income inequality in the US has rapidly increased in recent decades, reaching extreme levels. Based on a recent report published by a group of prominent researchers, while typical earners experienced only a meager $7 \%$ increase in their wages between 2000 and 2018, the richest $5 \%$ experienced a $25 \%$ increase in earnings.

THIS TEXT IS PRESENTED TO RESPONDENTS IN AN UNLISTED YOUTUBE VIDEO WITH SUBTITLES AND THE FOLLOWING LICENSED ADOBE STOCK IMAGE IN THE BACKGROUND.

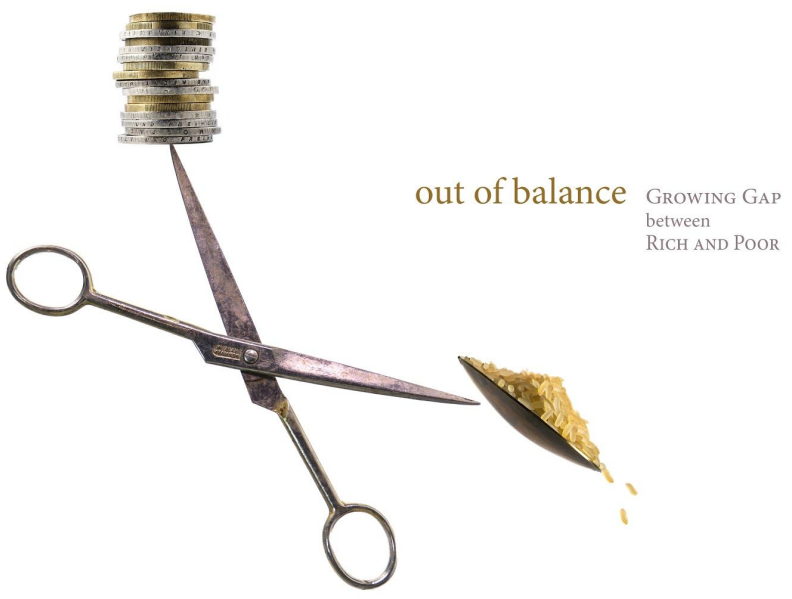

(C) Maren Winter - Adobe Stock

\section{LINK TO VIDEO}

IF INEQUALITY CONDITION = OPTIMISTIC

IF ANSWER = Decreased (More wealth for most) OR Stayed the same That is correct! Income inequality in the US has stopped growing. Based on a recent report published by a group of prominent researchers, income inequality today is practically the same as income inequality in 2000. As a matter of fact, economic inequality actually decreased during the period 2007 to 2014 .

THIS TEXT IS PRESENTED TO RESPONDENTS IN AN UNLISTED YOUTUBE VIDEO WITH SUBTITLES AND THE FOLLOWING LICENSED ADOBE STOCK IMAGE IN THE BACKGROUND. 


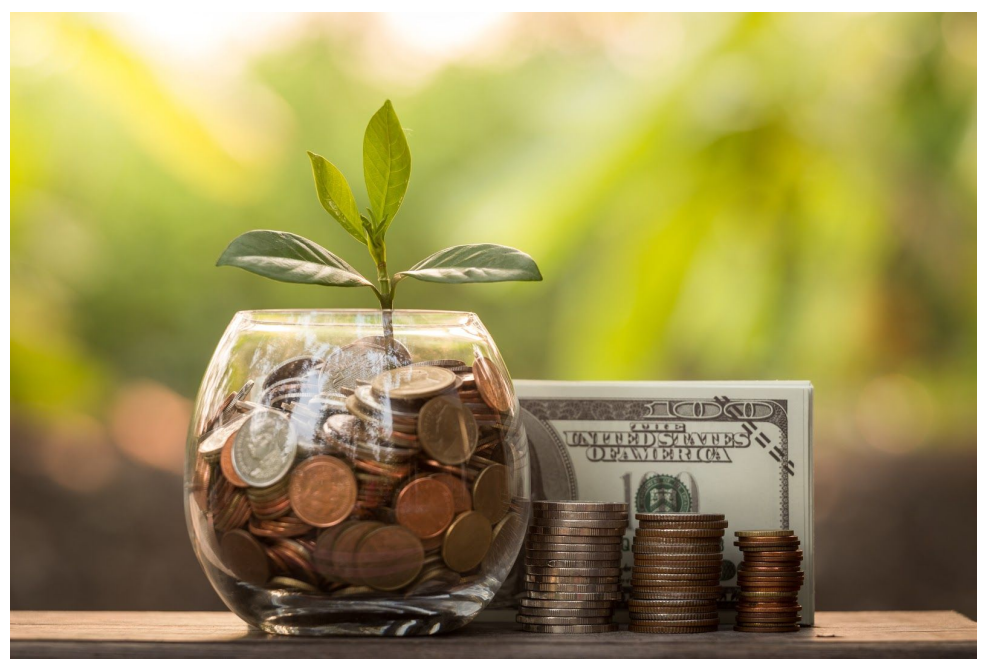

(C) PRASERT - Adobe Stock

\section{LINK TO VIDEO}

\section{ELSE}

Not quite. Income inequality in the US has stopped growing. Based on a recent report published by a group of prominent researchers, income inequality today is practically the same as income inequality in 2000 . As a matter of fact, economic inequality actually decreased during the period 2007 to 2014.

THIS TEXT IS PRESENTED TO RESPONDENTS IN AN UNLISTED YOUTUBE VIDEO WITH SUBTITLES AND THE FOLLOWING LICENSED ADOBE STOCK IMAGE IN THE BACKGROUND.

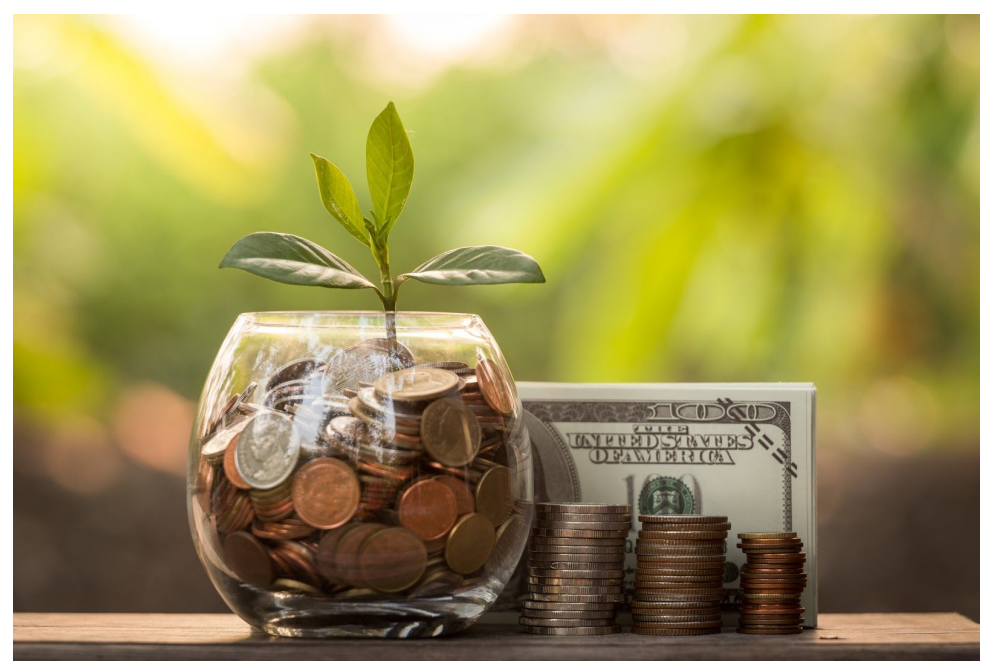

() PRASERT - Adobe Stock 
LINK TO VIDEO 


\section{Do you think economic mobility in the US has increased or decreased in recent decades?}

[Economic mobility can be defined as children doing better than their parents income-wise. High mobility generally means rising incomes for most Americans, while low mobility generally means falling incomes.]

- Decreased (Falling incomes for most)

- Stayed the same

- Increased (Rising incomes for most)

\section{IF MOBILITY CONDITION = PESSIMISTIC}

IF ANSWER = Decreased (Falling incomes for most)

That is correct! Economic mobility in the US is decreasing at an alarming rate. Based on a recent report published by a group of prominent researchers, while $90 \%$ of children were doing better than their parents in the 1970 s, only $51 \%$ of children today are doing better. Experts are interpreting this to mean that the American Dream is fading fast, and there is not enough opportunity for people to get ahead in life.

THIS TEXT IS PRESENTED TO RESPONDENTS IN AN UNLISTED YOUTUBE VIDEO WITH SUBTITLES AND THE FOLLOWING LICENSED ADOBE STOCK IMAGE IN THE BACKGROUND.

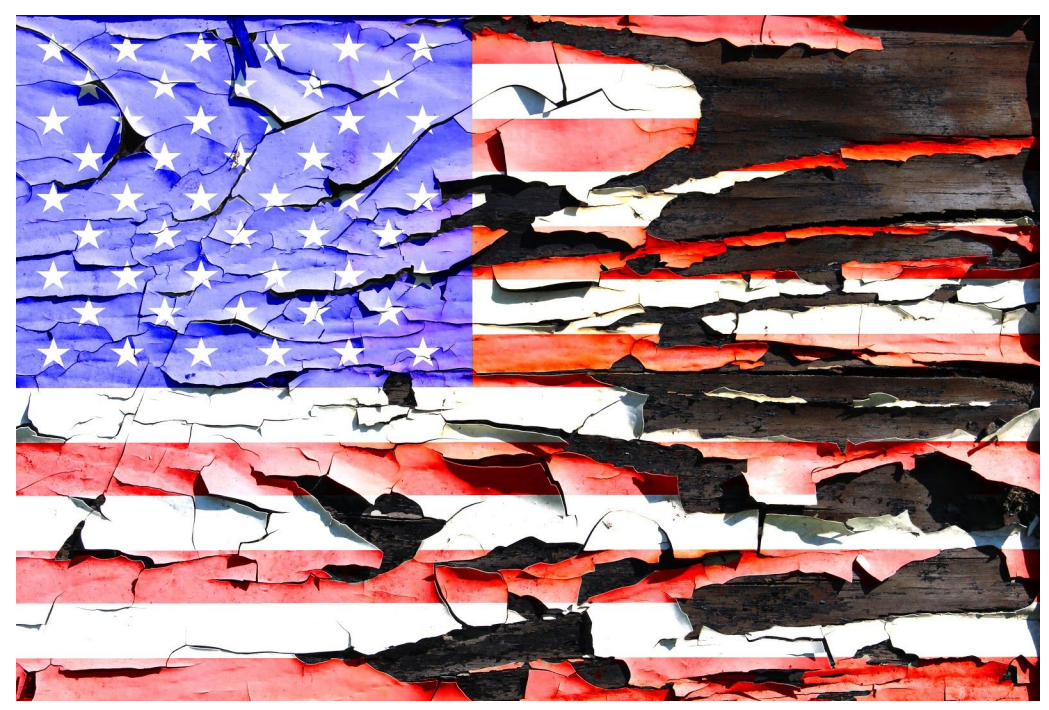

(C) Nikolai Grigoriev - Adobe Stock

\section{LINK TO VIDEO}


Not quite. Economic mobility in the US is decreasing at an alarming rate. Based on a recent report published by a group of prominent researchers, while $90 \%$ of children were doing better than their parents in the 1970 s, only $51 \%$ of children today are doing better. Experts are interpreting this to mean that the American Dream is fading fast, and there is not enough opportunity for people to get ahead in life.

THIS TEXT IS PRESENTED TO RESPONDENTS IN AN UNLISTED YOUTUBE VIDEO WITH SUBTITLES AND THE FOLLOWING LICENSED ADOBE STOCK IMAGE IN THE BACKGROUND.

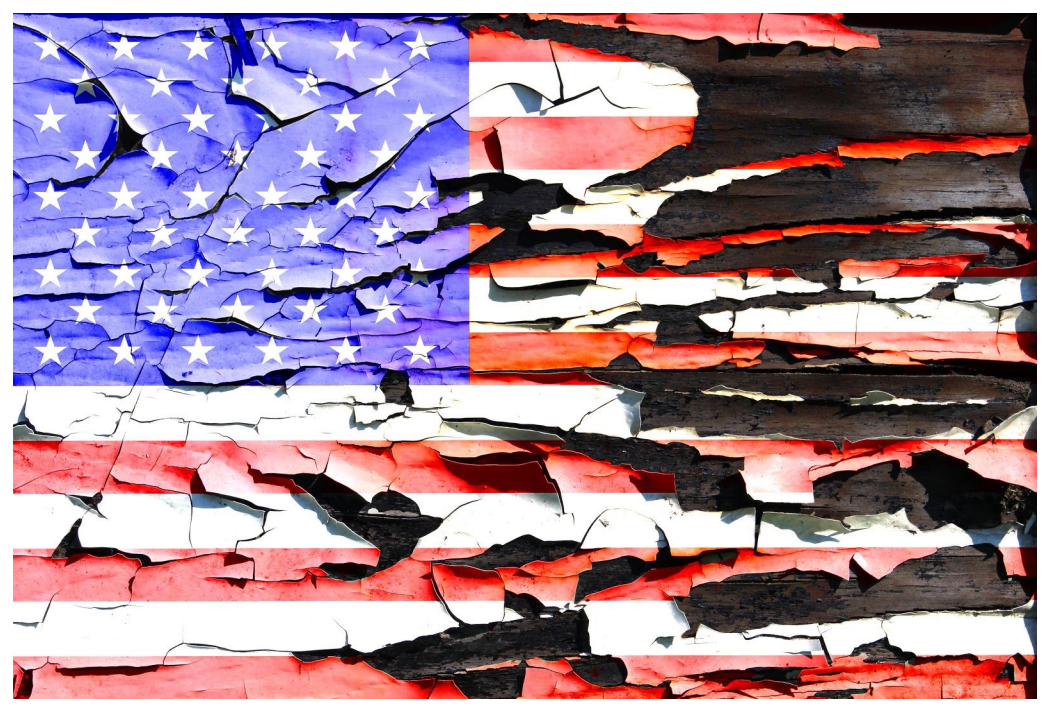

(c) Nikolai Grigoriev - Adobe Stock

\section{LINK TO VIDEO}

IF MOBILITY CONDITION = OPTIMISTIC

IF ANSWER = Increased (Rising incomes for most)

That is correct! Economic mobility in the US is on the rise. Based on a recent report published by a group of prominent researchers, $73 \%$ of children today are better off financially compared to their parents. Experts are interpreting this to mean that the American Dream is still alive, and there is plenty of opportunity for people to get ahead in life. 
THIS TEXT IS PRESENTED TO RESPONDENTS IN AN UNLISTED YOUTUBE VIDEO WITH SUBTITLES AND THE FOLLOWING LICENSED ADOBE STOCK IMAGE IN THE BACKGROUND.

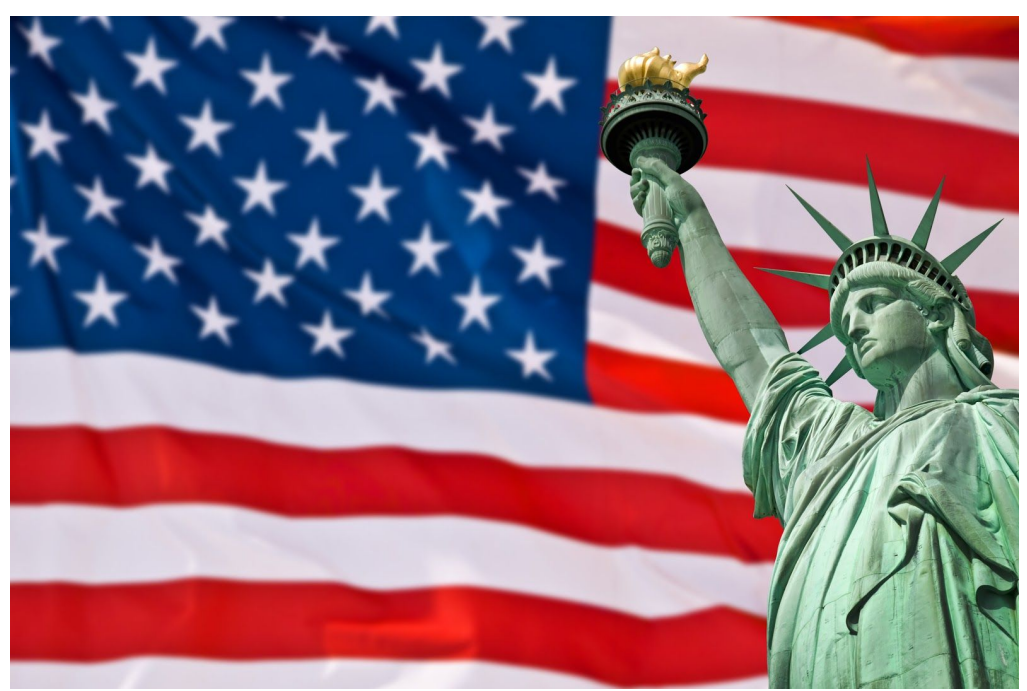

(C) Delphotostock - Adobe Stock

\section{LINK TO VIDEO}

\section{ELSE}

Not quite. Economic mobility in the US is on the rise. Based on a recent report published by a group of prominent researchers, $73 \%$ of children today are better off financially compared to their parents. Experts are interpreting this to mean that the American Dream is still alive, and there is plenty of opportunity for people to get ahead in life.

THIS TEXT IS PRESENTED TO RESPONDENTS IN AN UNLISTED YOUTUBE VIDEO WITH SUBTITLES AND THE FOLLOWING LICENSED ADOBE STOCK IMAGE IN THE BACKGROUND. 


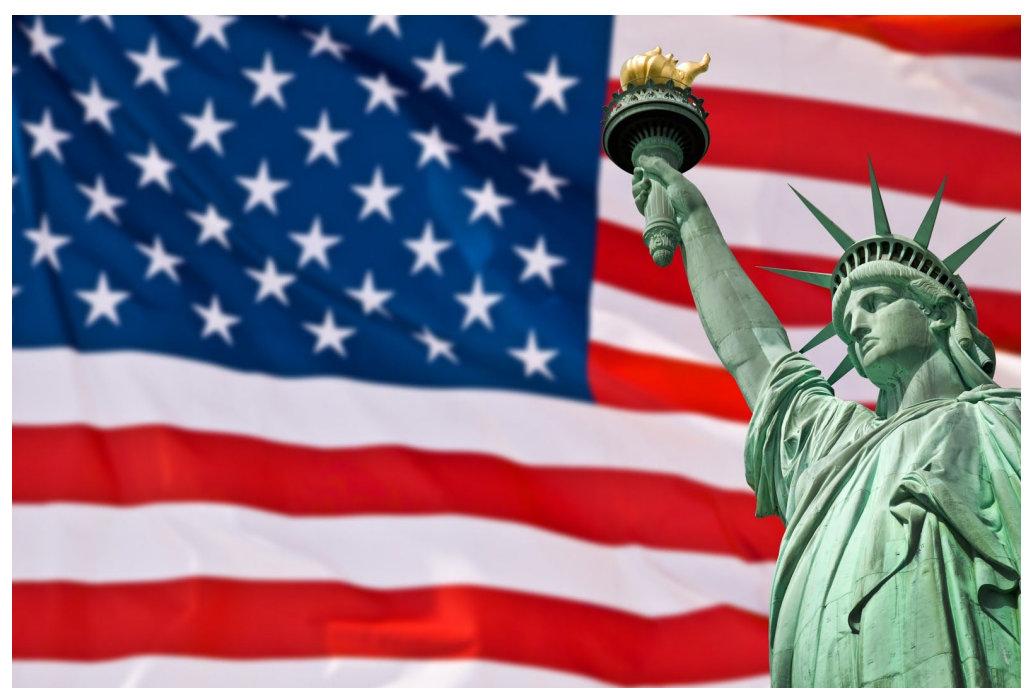

(c) Delphotostock - Adobe Stock

LINK TO VIDEO 
Now, we'll be asking you a few questions regarding your opinions on certain matters.

QUESTIONS WILL PRESENTED IN A RANDOM ORDER.

THE LAST TWO QUESTIONS ALWAYS APPEAR AT THE END. 
Which statement do you agree with most?

- One's income and position in society is mostly the result of one's individual effort

- One's income and position in society is to a large extent the outcome of elements outside of one's control (e.g., family background, luck, health issues)

Which do you favor: promoting equal opportunity or promoting equal outcomes?

[Equal opportunity can be defined as allowing everyone to compete for jobs and wealth on a fair and even basis. Equal outcomes can be defined as insuring that everyone has a decent standard of living and that there are only small differences in wealth and income between the top and bottom in society.]

- Equal opportunity

- Equal outcomes

Where would you rate yourself on a scale of 1 to 5 , where 1 means you think the government should do only those things necessary to provide the most basic government functions, and 5 means you think the government should take active steps in every area it can to try and improve the lives of its citizens?

- 1 - The government should do only those things necessary to provide the most basic government functions

- 2

- 3

- 4

- 5 - The government should take active steps in every area it can to try and improve the lives of its citizens 
Do you think inequality is a serious problem in America?

- Not a problem at all

- A small problem

- A problem

- A serious problem

- A very serious problem

Which of the tools below do you consider the best to address inequality in the United States?

[Please drag and drop the items below to rank them in your preferred order. Your most preferred method for addressing inequality should be at the top (1), your least preferred one at the bottom (5).]

- Education Policies

- Government Regulation (e.g., min wage, caps on top compensation)

- Government Transfers (e.g., food stamps, Medicaid)

- Private Charity

- Progressive Taxes

Describe in your own words what the government can do, if anything, to fix inequality in the US.

TEXT ENTRY HERE 
Do you think that the very high earners in our society deserve their high incomes?

- Most of the time

- Sometimes

- Rarely

Do you think income taxes on millionaires should be increased, stay the same or decreased?

- Increased

- Stay the same

- Decreased

Do you think the Federal Estate tax should be decreased, left as is or increased?

[The Federal Estate tax, also known as the Death Tax, is a tax imposed on the transfer of wealth from a deceased person to his or her heirs.]

- Increased

- Left as is

- Decreased 
Do you think the minimum wage should be decreased, stay the same or increased?

[The minimum wage is currently $\$ 7.25$ per hour.]

- Decreased

- Stay the same

- Increased

Should the federal government increase or decrease spending on aid to the poor?

- Significantly increase

- Slightly increase

- Keep at current level

- Slightly decrease

- Significantly decrease

Should the federal government increase or decrease its spending on food stamps?

[Food stamps provide financial assistance for food purchasing to families and individuals with low or no income.]

- Significantly increase

- Slightly increase

- Keep at current level

- Slightly decrease

- Significantly decrease

Should the federal government provide support for entrepreneurs (such as grants to help people start small businesses)?

- Yes

- No

Should the federal government help people in the face of high housing costs (such as creating opportunities for affordable housing)?

- Yes

- No 
Do you think the income gap between richer and poorer Americans are decreasing or increasing?

- Decreasing

- Same

- Increasing

Do you think American children today have better or worse chances economically compared to their parents?

- Better

- Same

- Worse 
Finally, please answer the following standard demographic questions. 
Are you a US resident?

- Yes

- No

In which state do you currently reside?

DROP-DOWN LIST OF STATES HERE 
What is your gender?

- Male

- Female

- Other

What is your age? [Enter a number (e.g., 35)]

TEXT ENTRY HERE

What is your marital status?

- Single

- Married

Do you have children living with you?

- Yes

- No 
How would you describe your ethnicity/race?

- European American/White

- African American/Black

- Hispanic/Latino

- Asian/Asian American

- Other

Which category best describes your highest level of education?

- Eighth Grade or Less

- Some High School

- High School Degree/GED

- Some College

- 2-year College Degree

- 4-year College Degree

- Master's Degree

- Doctoral Degree

- Professional Degree (JD, MD, MBA) 
What is your current employment status?

- Full-time employee

- Part-time employee

- Self-employed or small business owner

- Unemployed and looking for work

- Student

- Not in labor force (for example: retired, or full-time parent)

What was your TOTAL household income, before taxes, last year?

- $\$ 0-\$ 9,999$

- $\$ 10,000-\$ 14,999$

- $\$ 15,000-\$ 19,999$

- $\$ 20,000-\$ 29,999$

- $\$ 30,000-\$ 39,999$

- $\$ 40,000-\$ 49,999$

- $\$ 50,000-\$ 74,999$

- $\$ 75,000-\$ 99,999$

- $\$ 100,000-\$ 124,999$

- $\$ 125,000-\$ 149,999$

- $\$ 150,000-\$ 199,999$

- $\$ 200,000+$

Compared to your parents when they were the age you are now, do you think your own standard of living now is better or worse than theirs was?

- Much better

- Somewhat better

- About the same

- Somewhat worse

- Much worse

Compared to 10 years ago, do you think your standard of living now is better or worse?

- Much better

- Somewhat better

- About the same

- Somewhat worse

- Much worse 
Which best describes your household's income each month?

- Income is about the same each month

- Income varies somewhat from month to month

- Income varies a lot from month to month 
On economic policy matters, where do you see yourself on the liberal/conservative spectrum?

- Very conservative

- Conservative

- Moderate

- Liberal

- Very liberal

Generally speaking, do you usually think of yourself as a Republican, a Democrat, an Independent, or what?

- Republican

- Democrat

- Independent

- None 


\section{THE TEXT BELOW IS SHOWN TO RESPONDENTS BECAUSE IRB REQUIRES IT}

After submitting your responses, you can protect your privacy by clearing your browser's history, cache, cookies, and other browsing data. (Warning: This will log you out of online services.) 


\section{Appendix 2: Sample size calculations and variables}

\section{Sample size calculations}

Sample size calculations are made with the aim of being able to detect a small interaction effect in two-way ANOVA. Since the survey experiment employs a $2 \times 2$ factorial design, and since the interaction effect is of particular importance to the study, this approach is the right one to take. Calculations correct for multiple testing. The exact procedure used to calculate power is implemented in $\mathrm{R}$ in the powerInteract library as follows. (Source code can be publicly viewed at https://rdrr.io/cran/powerMediation/src/R/power_interaction.R.)

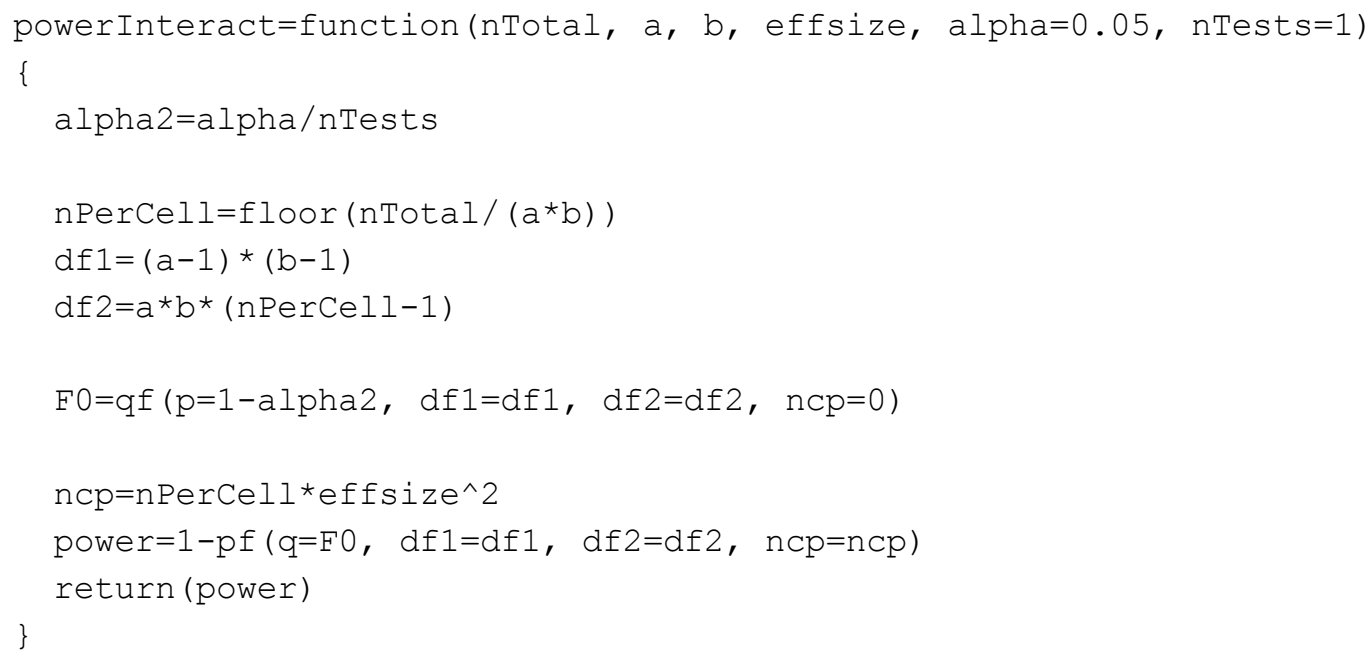

where:

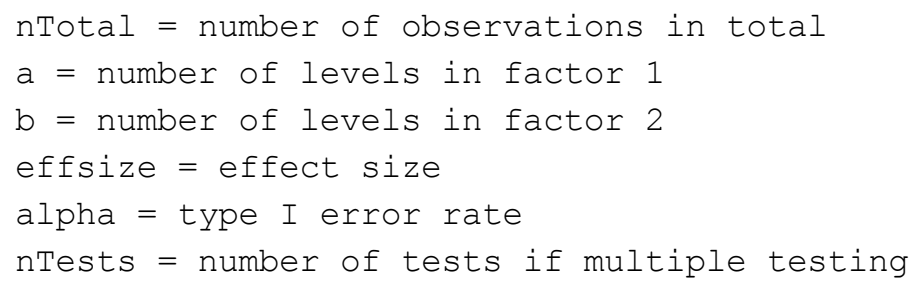

Using this function, and assuming a small effect size (Cohen's $d=0.15$ ) and 25 tests, a total of 2,800 respondents gives us more than $80 \%$ power to be able to detect the interaction effect. (Note that Cohen's $d$ is defined as mu/sigma, where mu is the raw effect size in the original scale and sigma is the standard deviation of the outcome variable.)

powerInteract (nTotal=2800, $a=2, b=2$, effsize=0.15, alpha=0.05, nTests=25) 
Given that it is harder to detect a small interaction effect compared to a small main effect, having enough power to detect a small interaction effect guarantees that we also have enough power to be able to detect the main effects.

\section{Additional variables}

In addition to the core variables mentioned in the main text, the dataset includes a set of auxiliary variables that can be helpful in later analyses:

- Respondent's answer to the economy quiz question

○ Categories: Less than 50\%; Around 50\%; More than 50\%

- Respondent's answer to the teen summer jobs quiz question

○ Categories: Less than 50\%; Around 50\%; More than 50\%

- Respondent's answer to the inequality quiz question

- Categories: Decreased (More wealth for most); Stayed the same; Increased (Less wealth for most)

- Respondent's answer to the mobility quiz question

○ Categories: Increased (Rising incomes for most); Stayed the same; Decreased (Falling incomes for most)

- Respondent's ranking of the methods for addressing inequality

- Categories: Education Policies; Government Regulation (e.g., min wage, caps on top compensation); Government Transfers (e.g., food stamps, Medicaid); Private Charity; Progressive Taxes

- Respondent's open-ended answer to what the government can do, if anything, to fix inequality

- Respondent's sense of their income volatility

- Categories: Income is about the same each month; Income varies somewhat from month to month; Income varies a lot from month to month

- Whether the inequality or the mobility treatment is shown first to the respondent

- The precise order in which the outcome questions are shown to the respondent

- Standard Qualtrics metadata including date, time, and duration of a survey session

\section{Distribution of respondents across states}

Respondents who took the survey come from all over the US. Table A2.1 below presents the distribution of respondents across the 50 states and DC.

Table A2.1. Total number of respondents in each state.

\begin{tabular}{|l|l|}
\hline State & Number of respondents \\
\hline Alabama & 40 \\
Alaska & 7 \\
Arizona & 66 \\
Arkansas & 20 \\
California & 273 \\
Colorado & 54 \\
Connecticut & 37 \\
Delaware & 10 \\
District of Columbia & 2 \\
Florida & 189 \\
\hline
\end{tabular}




\begin{tabular}{|c|c|}
\hline Georgia & 98 \\
\hline Hawaii & 9 \\
\hline Idaho & 19 \\
\hline Illinois & 90 \\
\hline Indiana & 52 \\
\hline Iowa & 32 \\
\hline Kansas & 23 \\
\hline Kentucky & 40 \\
\hline Louisiana & 36 \\
\hline Maine & 20 \\
\hline Maryland & 67 \\
\hline Massachusetts & 62 \\
\hline Michigan & 67 \\
\hline Minnesota & 28 \\
\hline Mississippi & 27 \\
\hline Missouri & 59 \\
\hline Montana & 15 \\
\hline Nebraska & 15 \\
\hline Nevada & 45 \\
\hline New Hampshire & 11 \\
\hline New Jersey & 78 \\
\hline New Mexico & 20 \\
\hline New York & 215 \\
\hline North Carolina & 92 \\
\hline North Dakota & 2 \\
\hline Ohio & 107 \\
\hline Oklahoma & 30 \\
\hline Oregon & 39 \\
\hline Pennsylvania & 142 \\
\hline Rhode Island & 14 \\
\hline South Carolina & 42 \\
\hline South Dakota & 9 \\
\hline Tennessee & 73 \\
\hline Texas & 185 \\
\hline Utah & 19 \\
\hline Vermont & 3 \\
\hline Virginia & 80 \\
\hline Washington & 68 \\
\hline West Virginia & 20 \\
\hline Wisconsin & 44 \\
\hline Wyoming & 5 \\
\hline Total & 2,800 \\
\hline
\end{tabular}




\section{Appendix 3: (Ordered) logit models}

The outcomes "income result of circumstances," "equal outcomes," "support entprens," and "support housing" are modeled using logistic regression. All other outcomes are modeled using ordered logistic regression. The upper side of each table includes as predictors only the two experimental factors and their interaction, while the lower side of the table also controls for the existing demographic covariates: age (mean-centered), gender (reference category: male), marital status (reference category: single), has children living with them (reference category: no), ethnicity/race (reference category: European American/White), highest level of education (reference category: some college), employment status (reference category: full-time employee), total household income before taxes (reference category: \$40,000 - \$49,999), liberal/conservative spectrum (reference category: moderate), and party identity (reference category: independent).

Table A3.1. Perception outcomes.

Models w/o any demographic covariates

\begin{tabular}{|l|l|l|l|l|}
\hline & $\begin{array}{l}\text { Income gap } \\
\text { increasing }\end{array}$ & $\begin{array}{l}\text { Children have } \\
\text { worse chances }\end{array}$ & $\begin{array}{l}\text { Inter-gen. } \\
\text { mobility down }\end{array}$ & $\begin{array}{l}\text { Intra-gen. } \\
\text { mobility down }\end{array}$ \\
\hline Ineq. pessimistic & $1.809(0.191)^{* * *}$ & $1.006(0.102)$ & $1.177(0.112)^{*}$ & $1.160(0.109)$ \\
\hline Opp. pessimistic & $1.377(0.142)^{* *}$ & $3.743(0.385)^{* * *}$ & $1.517(0.144)^{* * *}$ & $1.324(0.125)^{* *}$ \\
\hline Ineq. pessimistic x Opp. pessimistic & $0.891(0.136)$ & $0.865(0.125)$ & $0.733(0.099)^{*}$ & $0.892(0.120)$ \\
\hline
\end{tabular}

Models w/ demographic covariates

\begin{tabular}{|l|l|l|l|l|}
\hline & $\begin{array}{l}\text { Income gap } \\
\text { increasing }\end{array}$ & $\begin{array}{l}\text { Children have } \\
\text { worse chances }\end{array}$ & $\begin{array}{l}\text { Inter-gen. } \\
\text { mobility down }\end{array}$ & $\begin{array}{l}\text { Intra-gen. } \\
\text { mobility down }\end{array}$ \\
\hline Ineq. pessimistic & $1.937(0.212)^{* * *}$ & $1.010(0.106)$ & $1.182(0.115)^{*}$ & $1.217(0.117)^{*}$ \\
\hline Opp. pessimistic & $1.359(0.145)^{* *}$ & $4.001(0.425)^{* * *}$ & $1.582(0.153)^{* * *}$ & $1.334(0.129)^{* *}$ \\
\hline Ineq. pessimistic x Opp. pessimistic & $0.914(0.145)$ & $0.892(0.133)$ & $0.711(0.098)^{*}$ & $0.859(1.118)$ \\
\hline
\end{tabular}

Coefficient estimates are in odds ratios. The numbers inside the parentheses are standard errors. Stars denote $\mathrm{p}$-values: ${ }^{\bullet} \mathrm{p}<0.1,{ }^{*}$ $\mathrm{p}<0.05, * * \mathrm{p}<0.01, * * * \mathrm{p}<0.001$.

Table A3.2. Attitudinal outcomes.

Models w/o any demographic covariates

\begin{tabular}{|l|l|l|l|l|l|}
\hline & $\begin{array}{l}\text { Income result of } \\
\text { circumstances }\end{array}$ & Equal outcomes & $\begin{array}{l}\text { Government should } \\
\text { take active steps }\end{array}$ & $\begin{array}{l}\text { Inequality is a } \\
\text { serious problem }\end{array}$ & $\begin{array}{l}\text { High earners } \\
\text { rarely deserving }\end{array}$ \\
\hline Ineq. pessimistic & $1.133(0.121)$ & $1.125(0.135)$ & $1.292(0.123)^{* *}$ & $1.511(0.145)^{* * *}$ & $1.182(0.121)$ \\
\hline Opp. pessimistic & $1.057(0.113)$ & $1.056(0.128)$ & $1.201(0.115)^{*}$ & $1.350(0.129)^{* *}$ & $1.052(0.108)$ \\
\hline $\begin{array}{l}\text { Ineq. pessimistic } \mathrm{x} \\
\text { Opp. pessimistic }\end{array}$ & $1.006(0.152)$ & $0.887(0.151)$ & $0.715(0.097)^{*}$ & $0.732(0.099)^{*}$ & $0.970(0.142)$ \\
\hline
\end{tabular}

Models w/ demographic covariates 


\begin{tabular}{|l|l|l|l|l|l|}
\hline & $\begin{array}{l}\text { Income result of } \\
\text { circumstances }\end{array}$ & Equal outcomes & $\begin{array}{l}\text { Government should } \\
\text { take active steps }\end{array}$ & $\begin{array}{l}\text { Inequality is a } \\
\text { serious problem }\end{array}$ & $\begin{array}{l}\text { High earners } \\
\text { rarely deserving }\end{array}$ \\
\hline Ineq. pessimistic & $1.149(0.131)$ & $1.100(0.138)$ & $1.331(0.130)^{* *}$ & $1.570(0.153)^{* * *}$ & $1.182(0.124)$ \\
\hline Opp. pessimistic & $1.007(0.115)$ & $1.025(0.129)$ & $1.178(0.116)^{\circ}$ & $1.369(0.134)^{* *}$ & $1.010(0.106)$ \\
\hline $\begin{array}{l}\text { Ineq. pessimistic } \mathrm{x} \\
\text { Opp. pessimistic }\end{array}$ & $1.102(0.178)$ & $0.938(0.167)$ & $0.736(0.103)^{*}$ & $0.764(0.106)^{\cdot}$ & $1.043(0.156)$ \\
\hline
\end{tabular}

Coefficient estimates are in odds ratios. The numbers inside the parentheses are standard errors. Stars denote $p$-values: ${ }^{\prime} p<0.1,{ }^{*}$ $\mathrm{p}<0.05, * * \mathrm{p}<0.01, * * * \mathrm{p}<0.001$.

Table A3.3. Policy outcomes.

Models w/o any demographic covariates

\begin{tabular}{|l|l|l|l|l|l|l|l|}
\hline & $\begin{array}{l}\text { Increase } \\
\text { taxes on } \\
\text { millionaires }\end{array}$ & $\begin{array}{l}\text { Increase } \\
\text { estate tax }\end{array}$ & $\begin{array}{l}\text { Increase } \\
\text { minimum } \\
\text { wage }\end{array}$ & $\begin{array}{l}\text { Increase aid } \\
\text { to the poor }\end{array}$ & $\begin{array}{l}\text { Increase } \\
\text { spending on } \\
\text { food stamps }\end{array}$ & $\begin{array}{l}\text { Support } \\
\text { entprens }\end{array}$ & $\begin{array}{l}\text { Support } \\
\text { housing }\end{array}$ \\
\hline $\begin{array}{l}\text { Ineq. } \\
\text { pessimistic }\end{array}$ & $\begin{array}{l}1.050 \\
(0.116)\end{array}$ & $\begin{array}{l}1.213 \\
(0.121)\end{array}$ & $\begin{array}{l}1.400 \\
(0.170)^{* *}\end{array}$ & $\begin{array}{l}1.147 \\
(0.110)\end{array}$ & $\begin{array}{l}1.058 \\
(0.100)\end{array}$ & $\begin{array}{l}1.061 \\
(0.156)\end{array}$ & $\begin{array}{l}1.348 \\
(0.203)^{*}\end{array}$ \\
\hline $\begin{array}{l}\text { Opp. } \\
\text { pessimistic }\end{array}$ & $\begin{array}{l}1.056 \\
(0.118)\end{array}$ & $\begin{array}{l}1.045 \\
(0.105)\end{array}$ & $\begin{array}{l}1.195 \\
(0.142)\end{array}$ & $\begin{array}{l}1.045 \\
(0.100)\end{array}$ & $\begin{array}{l}0.989 \\
(0.094)\end{array}$ & $\begin{array}{l}0.984 \\
(0.143)\end{array}$ & $\begin{array}{l}(.069 \\
(0.155)\end{array}$ \\
\hline $\begin{array}{l}\text { Ineq. } \\
\text { pessimistic } \mathrm{x} \\
\begin{array}{l}\text { Opp. } \\
\text { pessimistic }\end{array}\end{array}$ & $\begin{array}{l}1.030 \\
(0.164)\end{array}$ & $\begin{array}{l}0.893 \\
(0.127)\end{array}$ & $\begin{array}{l}0.744 \\
(0.128)\end{array}$ & $\begin{array}{l}0.979 \\
(0.134)\end{array}$ & $\begin{array}{l}1.045 \\
(0.141)\end{array}$ & $\begin{array}{l}0.996 \\
(0.207)\end{array}$ & $\begin{array}{l}0.706 \\
(0.148)\end{array}$ \\
\hline
\end{tabular}

\section{Models w/ demographic covariates}

\begin{tabular}{|l|l|l|l|l|l|l|l|}
\hline & $\begin{array}{l}\text { Increase } \\
\text { taxes on } \\
\text { millionaires }\end{array}$ & $\begin{array}{l}\text { Increase } \\
\text { estate tax }\end{array}$ & $\begin{array}{l}\text { Increase } \\
\text { minimum } \\
\text { wage }\end{array}$ & $\begin{array}{l}\text { Increase aid } \\
\text { to the poor }\end{array}$ & $\begin{array}{l}\text { Increase } \\
\text { spending on } \\
\text { food stamps }\end{array}$ & $\begin{array}{l}\text { Support } \\
\text { entprens }\end{array}$ & $\begin{array}{l}\text { Support } \\
\text { housing }\end{array}$ \\
\hline $\begin{array}{l}\text { Ineq. } \\
\text { pessimistic }\end{array}$ & $\begin{array}{l}1.048 \\
(0.123)\end{array}$ & $\begin{array}{l}1.226 \\
(0.126)^{*}\end{array}$ & $\begin{array}{l}1.435 \\
(0.185)^{* *}\end{array}$ & $\begin{array}{l}1.138 \\
(0.111)\end{array}$ & $\begin{array}{l}1.057 \\
(0.103)\end{array}$ & $\begin{array}{l}1.061 \\
(0.159)\end{array}$ & $\begin{array}{l}1.395 \\
(0.222)^{*}\end{array}$ \\
\hline $\begin{array}{l}\text { Opp. } \\
\text { pessimistic }\end{array}$ & $\begin{array}{l}1.010 \\
(0.119)\end{array}$ & $\begin{array}{l}1.052 \\
(0.109)\end{array}$ & $\begin{array}{l}1.179 \\
(0.149)\end{array}$ & $\begin{array}{l}1.003 \\
(0.098)\end{array}$ & $\begin{array}{l}0.976 \\
(0.095)\end{array}$ & $\begin{array}{l}0.947 \\
(0.141)\end{array}$ & $\begin{array}{l}1.052 \\
(0.162)\end{array}$ \\
\hline $\begin{array}{l}\text { Ineq. } \\
\text { pessimistic } \mathrm{x} \\
\begin{array}{l}\text { Opp. } \\
\text { pessimistic }\end{array}\end{array}$ & $\begin{array}{l}(0.087 \\
(0.183)\end{array}$ & $\begin{array}{l}0.917 \\
(0.134)\end{array}$ & $\begin{array}{l}0.755 \\
(0.138)\end{array}$ & $\begin{array}{l}1.061 \\
(0.147)\end{array}$ & $\begin{array}{l}1.132 \\
(0.156)\end{array}$ & $\begin{array}{l}1.029 \\
(0.218)\end{array}$ & $\begin{array}{l}0.703 \\
(0.156)\end{array}$ \\
\hline
\end{tabular}

Coefficient estimates are in odds ratios. The numbers inside the parentheses are standard errors. Stars denote $p$-values: ${ }^{\prime} p<0.1, *$ $\mathrm{p}<0.05, * * \mathrm{p}<0.01, * * * \mathrm{p}<0.001$. 


\section{Appendix 4: OLS models}

See Figure A4.1 for the outcome means in the four conditions corresponding to the outcomes not presented in the main text (first three are related to general attitudes and latter four are policy outcomes). See Tables A4.1 through A4.3 for the estimated inequality, opportunity, and interaction effects reported in the main text. The upper side of each table includes as predictors only the two experimental factors and their interaction, while the lower side of the table also controls for the existing demographic covariates: age (mean-centered), gender (reference category: male), marital status (reference category: single), has children living with them (reference category: no), ethnicity/race (reference category: European American/White), highest level of education (reference category: some college), employment status (reference category: full-time employee), total household income before taxes (reference category: $\$ 40,000$ $\$ 49,999$ ), liberal/conservative spectrum (reference category: moderate), and party identity (reference category: independent). These effect estimates are also visualized in Figures A4.2 through A4.6.

Table A4.1. Perception outcomes.

Models w/o any demographic covariates

\begin{tabular}{|l|l|l|l|l|}
\hline & $\begin{array}{l}\text { Income gap } \\
\text { increasing }\end{array}$ & $\begin{array}{l}\text { Children have } \\
\text { worse chances }\end{array}$ & $\begin{array}{l}\text { Inter-gen. } \\
\text { mobility down }\end{array}$ & $\begin{array}{l}\text { Intra-gen. } \\
\text { mobility down }\end{array}$ \\
\hline Ineq. pessimistic & $0.196(0.037)^{* * *}$ & $0.004(0.044)$ & $0.120(0.064)^{*}$ & $0.110(0.065)^{\cdot}$ \\
\hline Opp. pessimistic & $0.106(0.037)^{* *}$ & $0.606(0.044)^{* * *}$ & $0.293(0.065)^{* * *}$ & $0.200(0.065)^{* *}$ \\
\hline Ineq. pessimistic x Opp. pessimistic & $-0.046(0.052)$ & $-0.074(0.063)$ & $-0.225(0.091)^{*}$ & $-0.080(0.092)$ \\
\hline
\end{tabular}

Models w/ demographic covariates

\begin{tabular}{|l|l|l|l|l|}
\hline & $\begin{array}{l}\text { Income gap } \\
\text { increasing }\end{array}$ & $\begin{array}{l}\text { Children have } \\
\text { worse chances }\end{array}$ & $\begin{array}{l}\text { Inter-gen. } \\
\text { mobility down }\end{array}$ & $\begin{array}{l}\text { Intra-gen. } \\
\text { mobility down }\end{array}$ \\
\hline Ineq. pessimistic & $0.201(0.036)^{* * *}$ & $0.002(0.043)$ & $0.118(0.060)^{\cdot}$ & $0.125(0.061)^{*}$ \\
\hline Opp. pessimistic & $0.095(0.036)^{* *}$ & $0.593(0.043)^{* * *}$ & $0.287(0.061)^{* * *}$ & $0.186(0.061)^{* *}$ \\
\hline Ineq. pessimistic x Opp. pessimistic & $-0.034(0.051)$ & $-0.053(0.061)$ & $-0.224(0.086)^{* *}$ & $-0.082(0.086)$ \\
\hline
\end{tabular}

The numbers inside the parentheses are standard errors. Stars denote $\mathrm{p}$-values: ${ }^{\prime} \mathrm{p}<0.1,{ }^{*} \mathrm{p}<0.05,{ }^{* *} \mathrm{p}<0.01,{ }^{* * *} \mathrm{p}<0.001$.

Table A4.2. Attitudinal outcomes.

Models w/o any demographic covariates

\begin{tabular}{|l|l|l|l|l|l|}
\hline & $\begin{array}{l}\text { Income result of } \\
\text { circumstances }\end{array}$ & Equal outcomes & $\begin{array}{l}\text { Government should } \\
\text { take active steps }\end{array}$ & $\begin{array}{l}\text { Inequality is a } \\
\text { serious problem }\end{array}$ & $\begin{array}{l}\text { High earners } \\
\text { rarely deserving }\end{array}$ \\
\hline Ineq. pessimistic & $0.031(0.027)$ & $0.023(0.024)$ & $0.198(0.073)^{* *}$ & $0.270(0.062)^{* * *}$ & $0.058(0.035)^{*}$ \\
\hline Opp. pessimistic & $0.014(0.027)$ & $0.010(0.024)$ & $0.136(0.073)^{*}$ & $0.201(0.062)^{* *}$ & $0.019(0.036)$ \\
\hline $\begin{array}{l}\text { Ineq. pessimistic x } \\
\text { Opp. pessimistic }\end{array}$ & $0.002(0.038)$ & $-0.024(0.033)$ & $-0.261(0.104)^{*}$ & $-0.211(0.088)^{*}$ & $-0.011(0.050)$ \\
\hline
\end{tabular}


Models w/ demographic covariates

\begin{tabular}{|l|l|l|l|l|l|}
\hline & $\begin{array}{l}\text { Income result of } \\
\text { circumstances }\end{array}$ & Equal outcomes & $\begin{array}{l}\text { Government should } \\
\text { take active steps }\end{array}$ & $\begin{array}{l}\text { Inequality is a } \\
\text { serious problem }\end{array}$ & $\begin{array}{l}\text { High earners } \\
\text { rarely deserving }\end{array}$ \\
\hline Ineq. pessimistic & $0.030(0.025)$ & $0.018(0.023)$ & $0.190(0.068)^{* *}$ & $0.262(0.056)^{* * *}$ & $0.055(0.034)$ \\
\hline Opp. pessimistic & $0.001(0.025)$ & $0.005(0.023)$ & $0.108(0.068)$ & $0.177(0.057)^{* *}$ & $0.009(0.034)$ \\
\hline $\begin{array}{l}\text { Ineq. pessimistic } \\
\text { Opp. pessimistic }\end{array}$ & $0.022(0.036)$ & $-0.012(0.033)$ & $-0.197(0.096)^{*}$ & $-0.157(0.080)^{*}$ & $0.009(0.048)$ \\
\hline
\end{tabular}

The numbers inside the parentheses are standard errors. Stars denote $\mathrm{p}$-values: ${ }^{\prime} \mathrm{p}<0.1,{ }^{*} \mathrm{p}<0.05,{ }^{* *} \mathrm{p}<0.01,{ }^{* * *} \mathrm{p}<0.001$.

Table A4.3. Policy outcomes.

Models w/o any demographic covariates

\begin{tabular}{|l|l|l|l|l|l|l|l|}
\hline & $\begin{array}{l}\text { Increase } \\
\text { taxes on } \\
\text { millionaires }\end{array}$ & $\begin{array}{l}\text { Increase } \\
\text { estate tax }\end{array}$ & $\begin{array}{l}\text { Increase } \\
\text { minimum } \\
\text { wage }\end{array}$ & $\begin{array}{l}\text { Increase aid } \\
\text { to the poor }\end{array}$ & $\begin{array}{l}\text { Increase } \\
\text { spending on } \\
\text { food stamps }\end{array}$ & $\begin{array}{l}\text { Support } \\
\text { entprens }\end{array}$ & $\begin{array}{l}\text { Support } \\
\text { housing }\end{array}$ \\
\hline $\begin{array}{l}\text { Ineq. } \\
\text { pessimistic }\end{array}$ & $\begin{array}{l}0.019 \\
(0.032)\end{array}$ & $\begin{array}{l}0.079 \\
(0.039)^{*}\end{array}$ & $\begin{array}{l}0.088 \\
(0.029)^{* *}\end{array}$ & $\begin{array}{l}0.098 \\
(0.059)\end{array}$ & $\begin{array}{l}0.042 \\
(0.064)\end{array}$ & $\begin{array}{l}0.008 \\
(0.019)\end{array}$ & $\begin{array}{l}0.038 \\
(0.019)\end{array}$ \\
\hline $\begin{array}{l}\text { Opp. } \\
\text { pessimistic }\end{array}$ & $\begin{array}{l}0.015 \\
(0.032)\end{array}$ & $\begin{array}{l}0.025 \\
(0.039)\end{array}$ & $\begin{array}{l}0.056 \\
(0.029)^{*}\end{array}$ & $\begin{array}{l}0.043 \\
(0.059)\end{array}$ & $\begin{array}{l}0.002 \\
(0.064)\end{array}$ & $\begin{array}{l}-0.002 \\
(0.019)\end{array}$ & $\begin{array}{l}0.009 \\
(0.019)\end{array}$ \\
\hline $\begin{array}{l}\text { Ineq. } \\
\text { pessimistic } \mathrm{x} \\
\begin{array}{l}\text { Opp. } \\
\text { pessimistic }\end{array}\end{array}$ & $\begin{array}{l}-0.008 \\
(0.046)\end{array}$ & $\begin{array}{l}-0.051 \\
(0.055)\end{array}$ & $\begin{array}{l}-0.090 \\
(0.041)^{*}\end{array}$ & $\begin{array}{l}-0.060 \\
(0.083)\end{array}$ & $\begin{array}{l}0.010 \\
(0.091)\end{array}$ & $\begin{array}{l}-0.0003 \\
(0.028)\end{array}$ & $\begin{array}{l}-0.045 \\
(0.027)\end{array}$ \\
\hline
\end{tabular}

Models w/ demographic covariates

\begin{tabular}{|l|l|l|l|l|l|l|l|}
\hline & $\begin{array}{l}\text { Increase } \\
\text { taxes on } \\
\text { millionaires }\end{array}$ & $\begin{array}{l}\text { Increase } \\
\text { estate tax }\end{array}$ & $\begin{array}{l}\text { Increase } \\
\text { minimum } \\
\text { wage }\end{array}$ & $\begin{array}{l}\text { Increase aid } \\
\text { to the poor }\end{array}$ & $\begin{array}{l}\text { Increase } \\
\text { spending on } \\
\text { food stamps }\end{array}$ & $\begin{array}{l}\text { Support } \\
\text { entprens }\end{array}$ & $\begin{array}{l}\text { Support } \\
\text { housing }\end{array}$ \\
\hline $\begin{array}{l}\text { Ineq. } \\
\text { pessimistic }\end{array}$ & $\begin{array}{l}0.016 \\
(0.031)\end{array}$ & $\begin{array}{l}0.078 \\
(0.037)^{*}\end{array}$ & $\begin{array}{l}0.082 \\
(0.027)^{* *}\end{array}$ & $\begin{array}{l}0.084 \\
(0.056)\end{array}$ & $\begin{array}{l}0.031 \\
(0.059)\end{array}$ & $\begin{array}{l}0.007 \\
(0.019)\end{array}$ & $\begin{array}{l}0.037 \\
(0.019)^{*}\end{array}$ \\
\hline $\begin{array}{l}\text { Opp. } \\
\text { pessimistic }\end{array}$ & $\begin{array}{l}0.003 \\
(0.031)\end{array}$ & $\begin{array}{l}0.025 \\
(0.038)\end{array}$ & $\begin{array}{l}0.044 \\
(0.027)\end{array}$ & $\begin{array}{l}0.022 \\
(0.056)\end{array}$ & $\begin{array}{l}-0.020 \\
(0.059)\end{array}$ & $\begin{array}{l}-0.007 \\
(0.019)\end{array}$ & $\begin{array}{l}0.007 \\
(0.019)\end{array}$ \\
\hline $\begin{array}{l}\text { Ineq. } \\
\text { pessimistic } \mathrm{x} \\
\begin{array}{l}\text { Opp. } \\
\text { pessimistic }\end{array}\end{array}$ & $\begin{array}{l}0.009 \\
(0.044)\end{array}$ & $\begin{array}{l}-0.037 \\
(0.053)\end{array}$ & $\begin{array}{l}-0.070 \\
(0.039)\end{array}$ & $\begin{array}{l}-0.011 \\
(0.079)\end{array}$ & $\begin{array}{l}0.065 \\
(0.084)\end{array}$ & $\begin{array}{l}0.005 \\
(0.028)\end{array}$ & $\begin{array}{l}-0.038 \\
(0.027)\end{array}$ \\
\hline
\end{tabular}

The numbers inside the parentheses are standard errors. Stars denote $\mathrm{p}$-values: ${ }^{\prime} \mathrm{p}<0.1,{ }^{*} \mathrm{p}<0.05,{ }^{* *} \mathrm{p}<0.01,{ }^{* * *} \mathrm{p}<0.001$. 

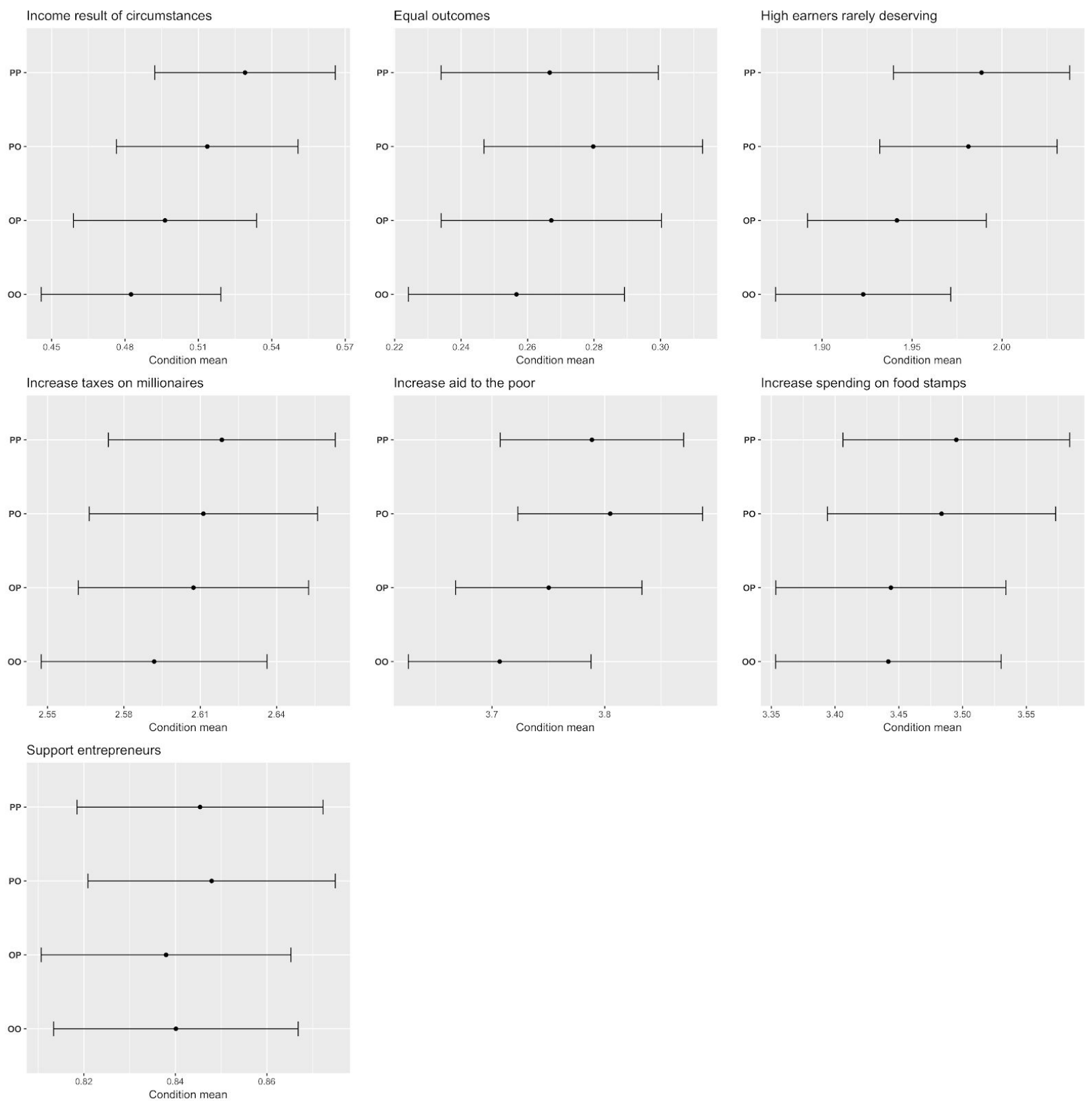

Fig. A4.1. Other outcomes (predicted means). The bars denote $95 \%$ confidence intervals. PP: inequality pessimistic, opportunity pessimistic; PO: inequality pessimistic, opportunity optimistic; OP: inequality optimistic, opportunity pessimistic; OO: inequality optimistic, opportunity optimistic. 

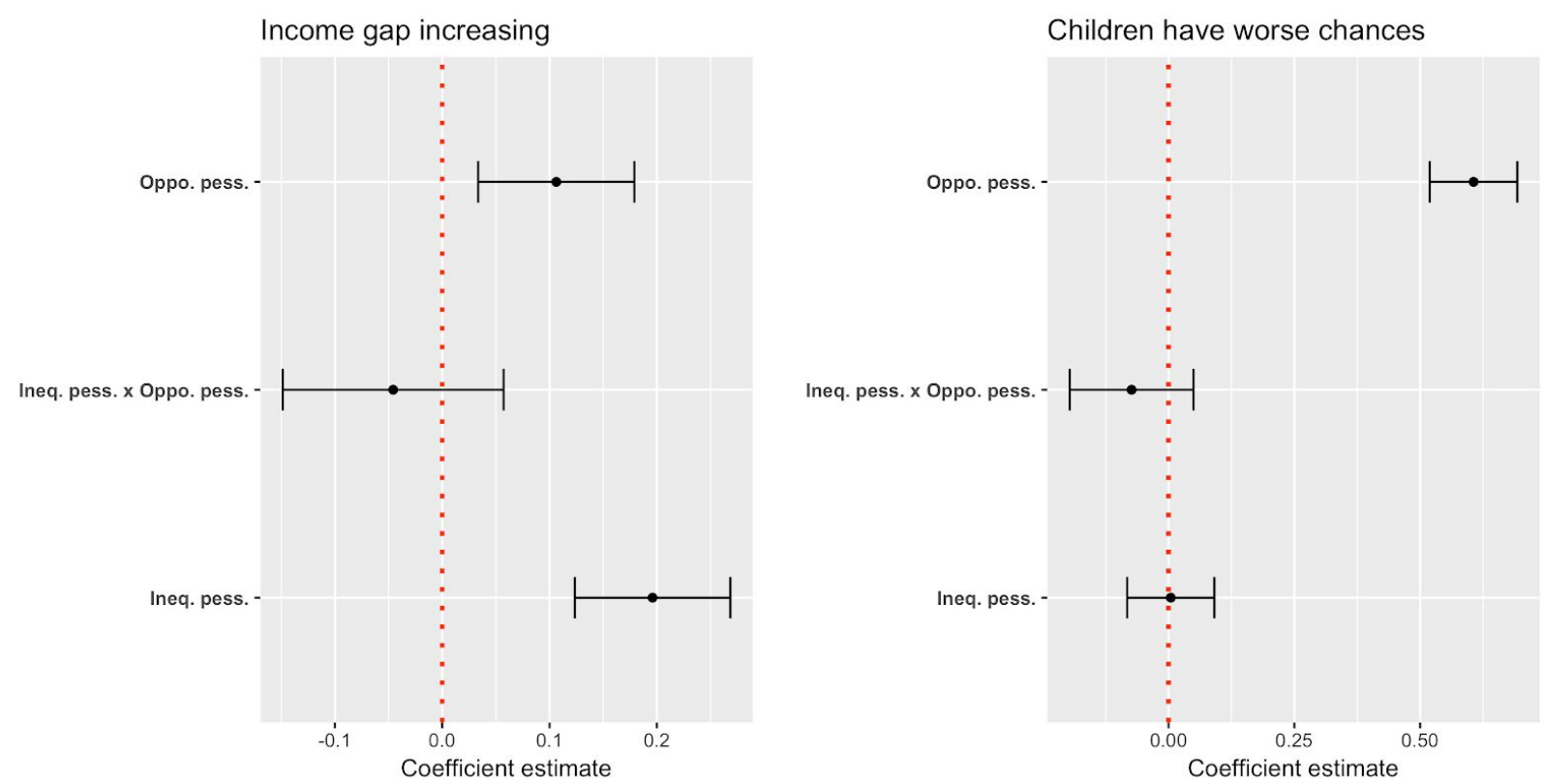

Fig. A4.2. Perceptions regarding inequality and opportunity (effect estimates). The bars denote $95 \%$ confidence intervals. The dashed red line at 0 corresponds to a null effect and is included to show which estimates are statistically significant. Ineq. pess.: inequality pessimistic; Oppo. pess.: opportunity pessimistic; Ineq. pess. x Oppo. pess.: the interaction term between inequality pessimistic and opportunity pessimistic.
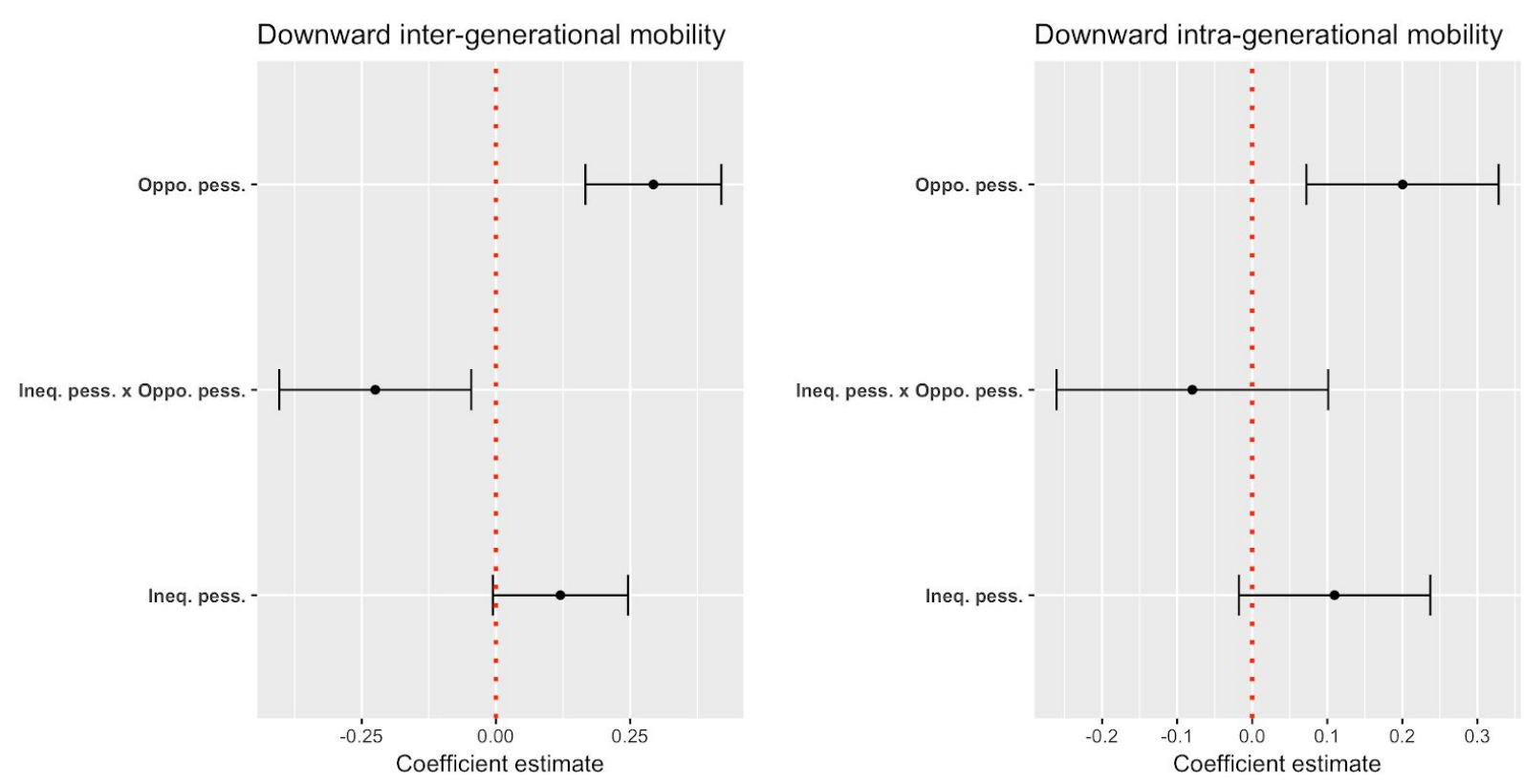

Fig. A4.3. Perceptions regarding mobility (effect estimates). The bars denote $95 \%$ confidence intervals. The dashed red line at 0 corresponds to a null effect and is included to show which estimates are statistically significant. Ineq. pess.: inequality pessimistic; Oppo. pess.: opportunity pessimistic; Ineq. pess. x Oppo. pess.: the interaction term between inequality pessimistic and opportunity pessimistic. 

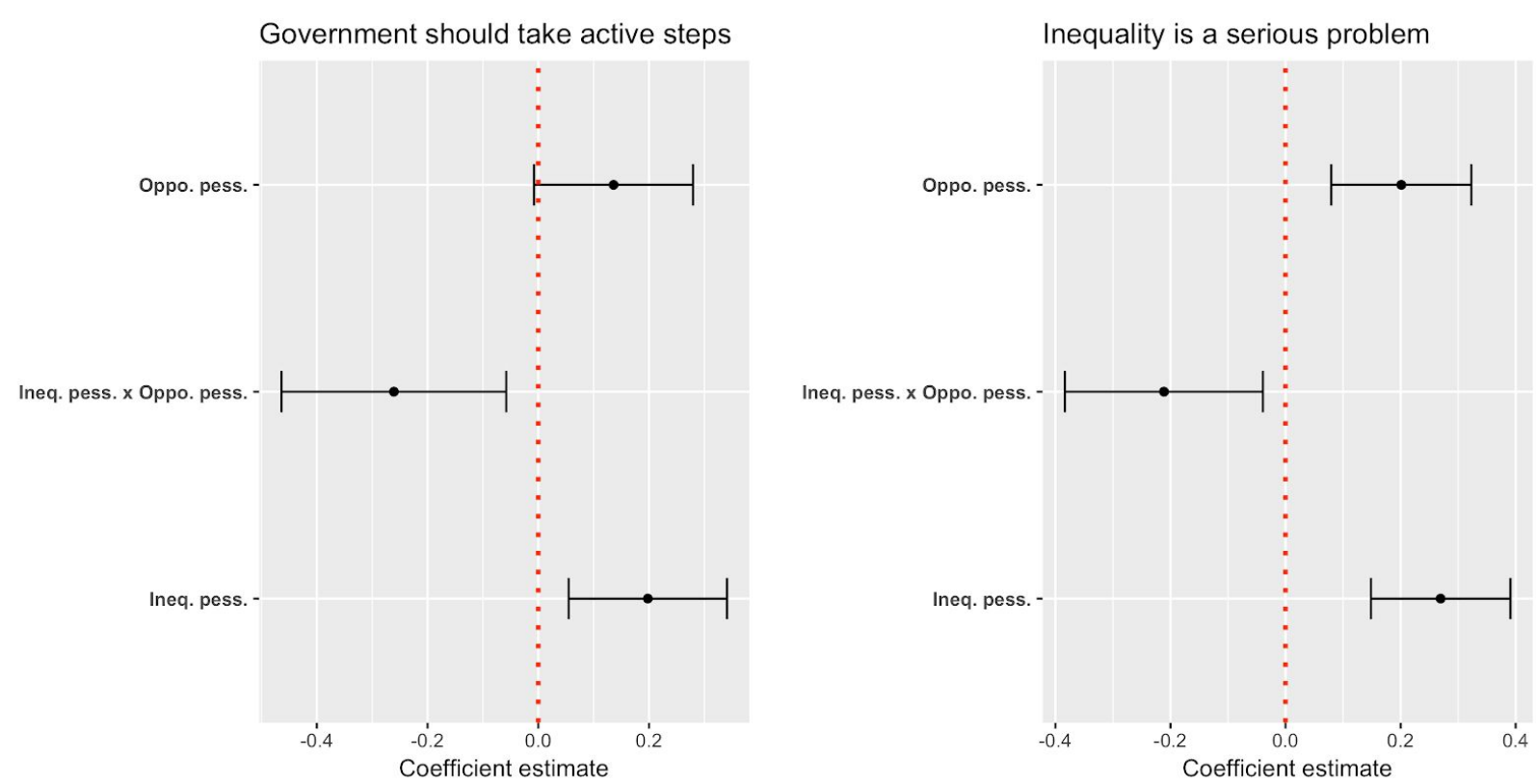

Fig. A4.4. General attitudes towards inequality (effect estimates). The bars denote $95 \%$ confidence intervals. The dashed red line at 0 corresponds to a null effect and is included to show which estimates are statistically significant. Ineq. pess.: inequality pessimistic; Oppo. pess.: opportunity pessimistic; Ineq. pess. x Oppo. pess.: the interaction term between inequality pessimistic and opportunity pessimistic.
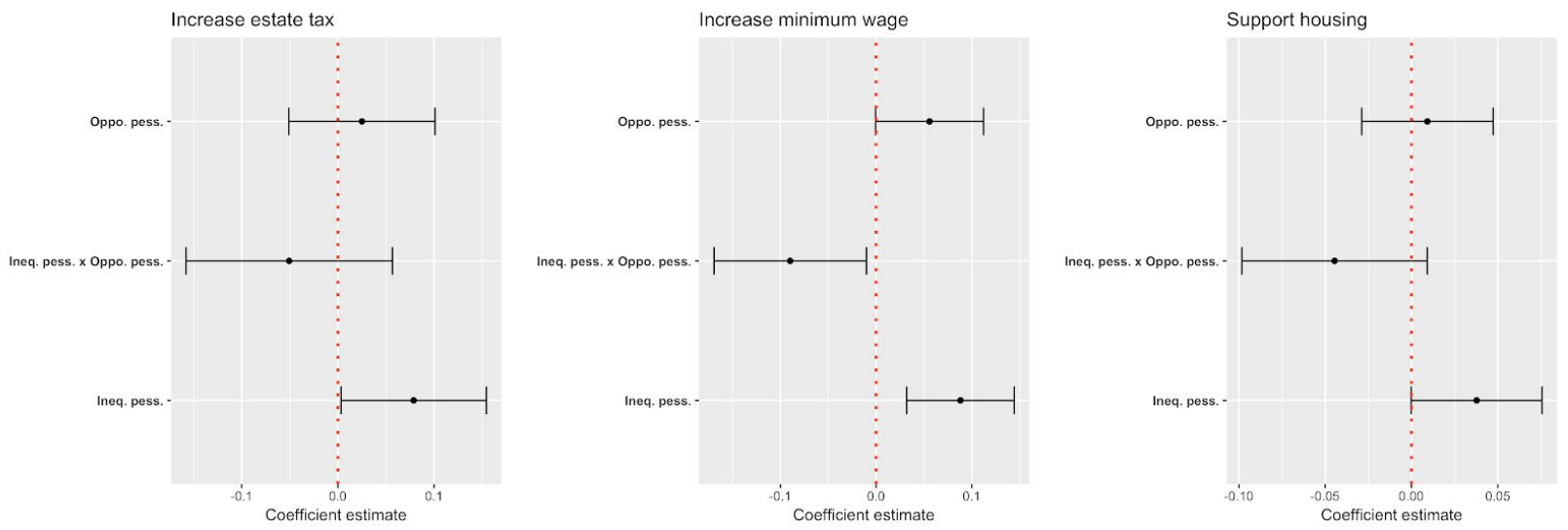

Fig. A4.5. Concrete policy preferences (effect estimates). The bars denote $95 \%$ confidence intervals. The dashed red line at 0 corresponds to a null effect and is included to show which estimates are statistically significant. Ineq. pess.: inequality pessimistic; Oppo. pess.: opportunity pessimistic; Ineq. pess. x Oppo. pess.: the interaction term between inequality pessimistic and opportunity pessimistic. 

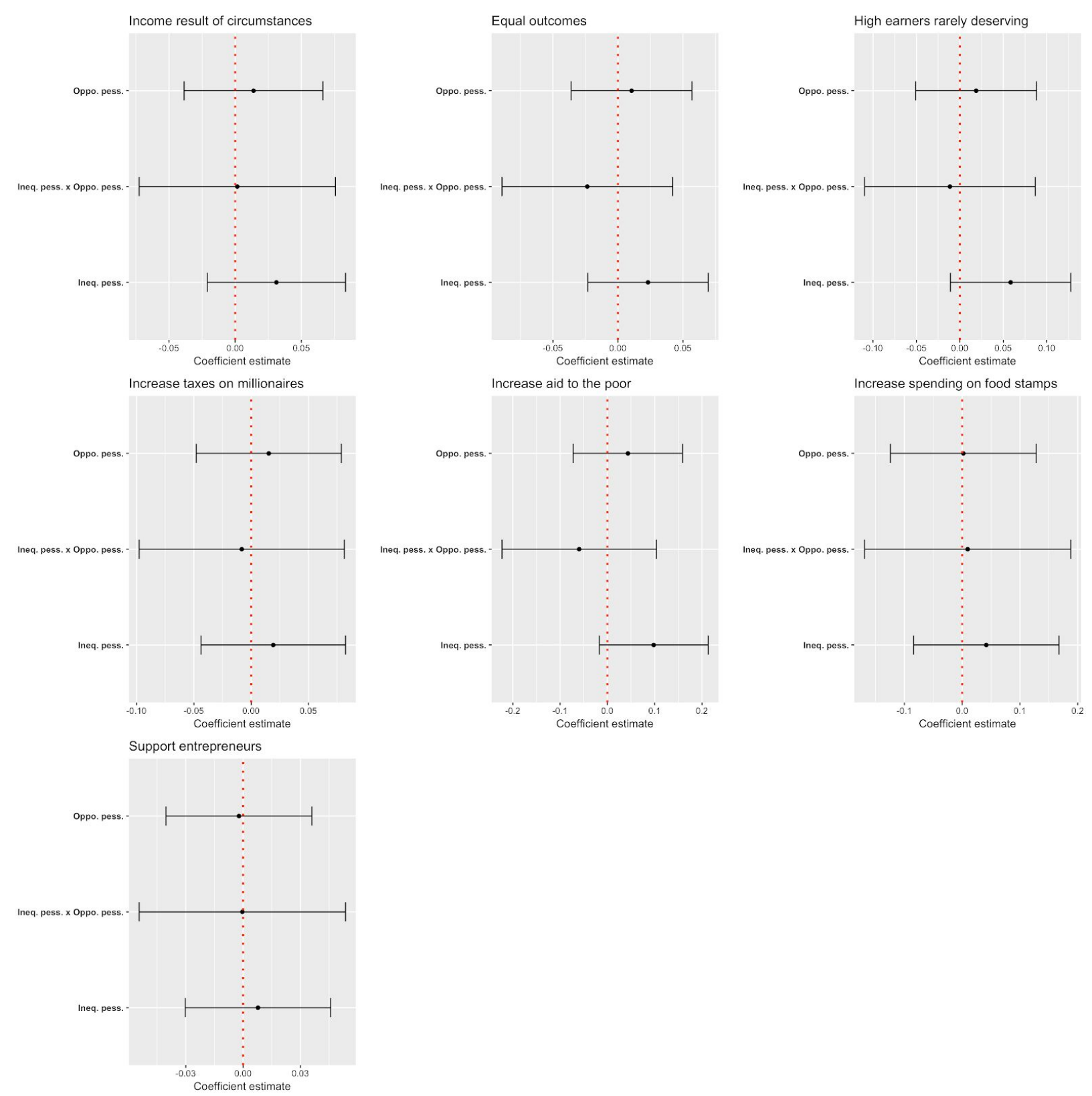

Fig. A4.6. Other outcomes (effect estimates). The bars denote $95 \%$ confidence intervals. The dashed red line at 0 corresponds to a null effect and is included to show which estimates are statistically significant. Ineq. pess.: inequality pessimistic; Oppo. pess.: opportunity pessimistic; Ineq. pess. x Oppo. pess.: the interaction term between inequality pessimistic and opportunity pessimistic. 


\section{Appendix 5: Interactions with political orientation}

Beyond the main goal of the study -- which is to estimate inequality and opportunity effects separately and jointly -- we can actually go one step further and see if these factors affect liberals and conservatives differently. In other words, given the known political divide in the country regarding how to address inequality, political orientation could be a significant moderator of the inequality and opportunity effects. For example, since liberals are already more inclined to support redistribution compared to conservatives, an informational treatment could be much more effective in swaying their preferences. In fact, Alesina, Stantcheva, and Teso (2018) finds that the pessimistic mobility effect in their study was mainly a result of a significant effect on left-wing respondents, while the treatment had little effect on right-wing respondents.

Accordingly, an additional set of models add interactions between the experimental predictors and political orientation (-2: very conservative, -1 : conservative, 0 : moderate, 1 : liberal, 2: very liberal). Table A5.1 below presents results from this last set of models. For the sake of space, only results where at least one of these interactions is significant at the $p<0.1$ level are presented; estimates from the other models are generally very similar to the results presented in earlier tables (Tables A4.1-3) and do not change our conclusions.

The first point to be noted here is that having a more liberal orientation is associated with a higher chance of (i) thinking that the income gap is increasing, (ii) thinking children today have worse chances compared to parents, (iii) thinking income and position in society is a result of circumstances, and (iv) giving support to policies that address inequality. (Liberal orientation also has a similar effect on the other outcomes not presented in this table.) None of these results are surprising given what we know about the liberal/conservative divide in the country.

The more interesting results from this table are those related to the interactions between political orientation and the experimental manipulations. Based on these estimates, we have some evidence to argue that (i) having a more liberal orientation leads to smaller increases in the chances of thinking the income gap is increasing when either of the treatments is pessimistic; (ii) having a more liberal orientation leads to larger increases in the chances of thinking children have worse chances when both informational treatments are pessimistic; (iii) having a more liberal orientation leads to larger increases in the chances of thinking income is the result of circumstances when either the inequality or the opportunity treatment is pessimistic, while it leads to smaller increases when both treatments are pessimistic (a similar pattern is observed also in the case of advocating for increasing estate tax); (iv) having a more liberal orientation leads to smaller increases in the chances of advocating for increasing minimum wage when the inequality treatment is pessimistic, while it leads to larger increases when both treatments are pessimistic (a similar pattern is observed also in the case of advocating for supporting entrepreneurs); and (v) having a more liberal orientation leads to smaller increases in the chances of advocating for housing support when the inequality treatment is pessimistic.

Table A5.1. Experimental manipulations and political orientation.

Models w/o any demographic covariates

\begin{tabular}{|l|l|l|l|l|l|l|l|}
\hline & $\begin{array}{l}\text { Income gap } \\
\text { increasing }\end{array}$ & $\begin{array}{l}\text { Children have } \\
\text { worse chances }\end{array}$ & $\begin{array}{l}\text { Income result of } \\
\text { circumstances }\end{array}$ & $\begin{array}{l}\text { Increase } \\
\text { estate tax }\end{array}$ & $\begin{array}{l}\text { Increase } \\
\text { minimum wage }\end{array}$ & $\begin{array}{l}\text { Support } \\
\text { entprens }\end{array}$ & $\begin{array}{l}\text { Support } \\
\text { housing }\end{array}$ \\
\hline Inequality pessimistic & $\begin{array}{l}0.183 \\
(0.036) * * *\end{array}$ & $\begin{array}{l}-0.001 \\
(0.043)\end{array}$ & $\begin{array}{l}0.032 \\
(0.026)\end{array}$ & $\begin{array}{l}0.085 \\
(0.038)^{*}\end{array}$ & $\begin{array}{l}0.076 \\
(0.028)^{*}\end{array}$ & $\begin{array}{l}-0.001 \\
(0.019)\end{array}$ & $\begin{array}{l}0.031 \\
(0.019)\end{array}$ \\
\hline
\end{tabular}




\begin{tabular}{|l|l|l|l|l|l|l|l|}
\hline $\begin{array}{l}\text { Opportunity } \\
\text { pessimistic }\end{array}$ & $\begin{array}{l}0.091 \\
(0.037)^{*}\end{array}$ & $\begin{array}{l}0.598 \\
(0.043)^{* * *}\end{array}$ & $\begin{array}{l}0.012 \\
(0.026)\end{array}$ & $\begin{array}{l}0.028 \\
(0.038)\end{array}$ & $\begin{array}{l}0.045 \\
(0.028)\end{array}$ & $\begin{array}{l}-0.006 \\
(0.020)\end{array}$ & $\begin{array}{l}0.006 \\
(0.019)\end{array}$ \\
\hline Ineq. x Opp. & $\begin{array}{l}-0.023 \\
(0.052)\end{array}$ & $\begin{array}{l}-0.030 \\
(0.061)\end{array}$ & $\begin{array}{l}0.010 \\
(0.037)\end{array}$ & $\begin{array}{l}-0.048 \\
(0.054)\end{array}$ & $\begin{array}{l}-0.056 \\
(0.039)\end{array}$ & $\begin{array}{l}0.013 \\
(0.028)\end{array}$ & $\begin{array}{l}-0.032 \\
(0.027)\end{array}$ \\
\hline Liberal & $\begin{array}{l}0.181 \\
(0.024)^{* * *}\end{array}$ & $\begin{array}{l}0.150 \\
(0.028)^{* * *}\end{array}$ & $\begin{array}{l}0.110 \\
(0.017)^{* * *}\end{array}$ & $\begin{array}{l}0.076 \\
(0.025)^{* *}\end{array}$ & $\begin{array}{l}0.153 \\
(0.018)^{* * *}\end{array}$ & $\begin{array}{l}0.051 \\
(0.013)^{* * *}\end{array}$ & $\begin{array}{l}0.081 \\
(0.012)^{* * *}\end{array}$ \\
\hline Ineq. x Liberal & $\begin{array}{l}-0.056 \\
(0.034)\end{array}$ & $\begin{array}{l}0.003 \\
(0.040)\end{array}$ & $\begin{array}{l}0.043 \\
(0.024)\end{array}$ & $\begin{array}{l}0.076 \\
(0.035)^{*}\end{array}$ & $\begin{array}{l}-0.053 \\
(0.026)^{*}\end{array}$ & $\begin{array}{l}-0.055 \\
(0.018)^{* *}\end{array}$ & $\begin{array}{l}-0.036 \\
(0.018)^{*}\end{array}$ \\
\hline Opp. x Liberal & $\begin{array}{l}-0.051 \\
(0.034)\end{array}$ & $\begin{array}{l}-0.001 \\
(0.040)\end{array}$ & $\begin{array}{l}0.041 \\
(0.024)\end{array}$ & $\begin{array}{l}0.070 \\
(0.036)\end{array}$ & $\begin{array}{l}-0.027 \\
(0.026)\end{array}$ & $\begin{array}{l}-0.012 \\
(0.018)\end{array}$ & $\begin{array}{l}0.008 \\
(0.018)\end{array}$ \\
\hline Ineq. x Opp. x Liberal & $\begin{array}{l}0.033 \\
(0.048)\end{array}$ & $\begin{array}{l}0.102 \\
(0.057)\end{array}$ & $\begin{array}{l}-0.075 \\
(0.034)^{*}\end{array}$ & $\begin{array}{l}-0.110 \\
(0.050)^{*}\end{array}$ & $\begin{array}{l}0.090 \\
(0.037)^{*}\end{array}$ & $\begin{array}{l}0.056 \\
(0.026)^{*}\end{array}$ & $\begin{array}{l}0.016 \\
(0.025)\end{array}$ \\
\hline
\end{tabular}

Models w/ demographic covariates

\begin{tabular}{|l|l|l|l|l|l|l|l|}
\hline & $\begin{array}{l}\text { Income gap } \\
\text { increasing }\end{array}$ & $\begin{array}{l}\text { Children have } \\
\text { worse chances }\end{array}$ & $\begin{array}{l}\text { Income result of } \\
\text { circumstances }\end{array}$ & $\begin{array}{l}\text { Increase } \\
\text { estate tax }\end{array}$ & $\begin{array}{l}\text { Increase } \\
\text { minimum wage }\end{array}$ & $\begin{array}{l}\text { Support } \\
\text { entprens }\end{array}$ & $\begin{array}{l}\text { Support } \\
\text { housing }\end{array}$ \\
\hline Inequality pessimistic & $\begin{array}{l}0.193 \\
(0.036)^{* * *}\end{array}$ & $\begin{array}{l}0.001 \\
(0.043)\end{array}$ & $\begin{array}{l}0.036 \\
(0.026)\end{array}$ & $\begin{array}{l}0.088 \\
(0.038)^{*}\end{array}$ & $\begin{array}{l}0.075 \\
(0.028)^{* *}\end{array}$ & $\begin{array}{l}-0.001 \\
(0.019)\end{array}$ & $\begin{array}{l}0.033 \\
(0.019)\end{array}$ \\
\hline $\begin{array}{l}\text { Opportunity } \\
\text { pessimistic }\end{array}$ & $\begin{array}{l}0.086 \\
(0.036)^{*}\end{array}$ & $\begin{array}{l}0.593 \\
(0.043)^{* * *}\end{array}$ & $\begin{array}{l}0.006 \\
(0.026)\end{array}$ & $\begin{array}{l}0.034 \\
(0.038)\end{array}$ & $\begin{array}{l}0.041 \\
(0.028)\end{array}$ & $\begin{array}{l}-0.010 \\
(0.020)\end{array}$ & $\begin{array}{l}0.007 \\
(0.019)\end{array}$ \\
\hline Ineq. x Opp. & $\begin{array}{l}-0.032 \\
(0.051)\end{array}$ & $\begin{array}{l}-0.033 \\
(0.061)\end{array}$ & $\begin{array}{l}0.013 \\
(0.036)\end{array}$ & $\begin{array}{l}-0.048 \\
(0.054)\end{array}$ & $\begin{array}{l}-0.057 \\
(0.039)\end{array}$ & $\begin{array}{l}0.015 \\
(0.028)\end{array}$ & $\begin{array}{l}-0.034 \\
(0.027)\end{array}$ \\
\hline Liberal & $\begin{array}{l}0.172 \\
(0.024)^{* * *}\end{array}$ & $\begin{array}{l}0.130 \\
(0.029)^{* * *}\end{array}$ & $\begin{array}{l}0.084 \\
(0.017)^{* * *}\end{array}$ & $\begin{array}{l}0.039 \\
(0.026)\end{array}$ & $\begin{array}{l}0.140 \\
(0.019)^{* * *}\end{array}$ & $\begin{array}{l}0.046 \\
(0.013)^{* *}\end{array}$ & $\begin{array}{l}0.061 \\
(0.013)^{* * *}\end{array}$ \\
\hline Ineq. x Liberal & $\begin{array}{l}-0.061 \\
(0.033)\end{array}$ & $\begin{array}{l}-0.004 \\
(0.040)\end{array}$ & $\begin{array}{l}0.041 \\
(0.024)\end{array}$ & $\begin{array}{l}0.073 \\
(0.035)^{*}\end{array}$ & $\begin{array}{l}-0.056 \\
(0.026)^{*}\end{array}$ & $\begin{array}{l}-0.056 \\
(0.018)^{* *}\end{array}$ & $\begin{array}{l}-0.036 \\
(0.017)^{*}\end{array}$ \\
\hline Opp. x Liberal & $\begin{array}{l}-0.065 \\
(0.034)\end{array}$ & $\begin{array}{l}-0.005 \\
(0.040)\end{array}$ & $\begin{array}{l}0.041 \\
(0.024)\end{array}$ & $\begin{array}{l}0.072 \\
(0.035)^{*}\end{array}$ & $\begin{array}{l}-0.031 \\
(0.026)\end{array}$ & $\begin{array}{l}-0.016 \\
(0.018)\end{array}$ & $\begin{array}{l}0.008 \\
(0.018)\end{array}$ \\
\hline Ineq. x Opp. x Liberal & $\begin{array}{l}0.037 \\
(0.047)\end{array}$ & $\begin{array}{l}0.103 \\
(0.057)\end{array}$ & $\begin{array}{l}-0.072 \\
(0.034)^{*}\end{array}$ & $\begin{array}{l}-0.097 \\
(0.050)\end{array}$ & $\begin{array}{l}0.090 \\
(0.036)^{*}\end{array}$ & $\begin{array}{l}0.064 \\
(0.026)^{*}\end{array}$ & $\begin{array}{l}0.020 \\
(0.025)\end{array}$ \\
\hline
\end{tabular}

The numbers inside the parentheses are standard errors. Stars denote $\mathrm{p}$-values: ${ }^{\prime} \mathrm{p}<0.1,{ }^{*} \mathrm{p}<0.05, * * \mathrm{p}<0.01, * * * \mathrm{p}<0.001$.

\section{Citations}

Alesina, A., S. Stantcheva, and E. Teso. 2018. "Intergenerational Mobility and Preferences for Redistribution." American Economic Review 108(2): 521-554. 